\title{
The thermal stealth flows of Santiaguito dome, Guatemala: Implications for the cooling and emplacement of dacitic block-lava flows
}

\author{
A.J.L. Harris* \\ L.P. Flynn \\ Hawai ${ }^{\prime} i$ Institute of Geophysics and Planetology/School of Ocean and Earth Science and Technology (HIGP/SOEST), \\ University of Hawai' $i$, 2525 Correa Road, Honolulu, Hawai' 'i 96822, USA
}

O. Matías

Instituto Nacional de Sismologia, Vulcanologia, Meteorologia e Hidrologia (INSIVUMEH), 7a Avenida 14-57, Zona 13, Guatemala City, Guatemala

W.I. Rose

Department of Geological Engineering and Sciences, Michigan Technological University, Houghton, Michigan 49931, USA

\section{ABSTRACT}

Thick, slow-moving block-lava flows are associated with extrusive activity in dacitic systems, where lava-core depressurization during flow-front collapse generates devastating block-and-ash flows. Dimensional and rare thermal data collected during January 2000 for an active dacitic block flow at Santiaguito (Guatemala) provide insight into cooling and emplacement mechanisms. Flow velocity was low $\left(12.5 \mathrm{~m} \cdot \mathrm{d}^{-1}\right)$, in spite of steep $\left(\geq 10^{\circ}\right)$ slopes, a result of the high viscosity $\left(>4 \times 10^{9} \mathrm{~Pa} \cdot \mathrm{s}\right)$ that we calculate for this flow. The flow surface consisted of a thick (1.9-3.4 m), cool $\left(40-111{ }^{\circ} \mathrm{C}\right)$ crust of meter-sized, subangular blocks. Extremely effective insulation by the thick crust results in model-derived core cooling of $\leq 0.08{ }^{\circ} \mathrm{C}^{-1} \mathbf{h}^{-1}$. These low cooling rates make block flows the most thermally efficient of all styles of lava-flow emplacement, allowing cooling-limited flow lengths of several kilometers, in spite of low eruption rates $\left(<0.5 \mathrm{~m}^{3} \cdot \mathrm{s}^{-1}\right)$. Flow-front observations along with a plug-flow model showed that collapse from the faster-moving flow top contributed to a caterpillar-track-type advance similar to that observed at basaltic 'a'a flows. Forward motion also caused toothpaste-like extrusions of the flow core through the frontal crust at basal and mar-

\footnotetext{
*E-mail: harris@pgd.hawaii.edu.
}

ginal shear zones. The axial part of the flow front was thicker than the marginal zones and was oversteepened. This geometry can be explained by a higher vertical velocity gradient in the axial zone, causing more frequent and larger-volume flow-front collapses. Axial-zone collapses also penetrate farther up flow, but not sufficiently to depressurize the flow core and generate a block-and-ash flow. For such a block-andash flow to occur, we calculate that an increase in velocity and/or thickness (due to increased slope or topographic confinement) must occur. Whereas low surface temperatures make block flows invisible to short-wave infrared sensors, the low velocity also contributes to the stealthy behavior of these flows. Their stealthy nature, however, masks the fact that they can extend many kilometers, moving block-and-ash flow sources closer to vulnerable communities.

Keywords: block-and-ash flow, block-lava flow, cooling, emplacement, Enhanced Thematic Mapper, Santiaguito, volcanology.

\section{INTRODUCTION}

Block lava was defined by Macdonald (1953) as having a surface characterized by individual fragments that are "relatively smooth polyhedral blocks bounded by dihedral angles, lacking the exceedingly rough and spinose character of typical 'a'a." Such flows are typically associated with basaltic andesite to dacite lava and display lower eruption temperatures with higher crystal contents, viscosities, and yield strengths than their basaltic ' $a$ ' a counterparts. This combination of factors is typically cited as resulting in short, thick flows with high aspect ratios and low velocities (e.g., Cas and Wright, 1987).

Although these features mean that blockflow inundation of down-flow communities is unlikely, block-and-ash flows derived from flow-front collapse pose an extreme hazard to the same communities (e.g., Yamamoto et al., 1993; Fujii and Nakada, 1999; Ui et al., 1999). The high velocity and temperature of such pyroclastic flows are such that they pose a threat to human life, being the most common cause of death due to volcanic activity in the past $400 \mathrm{yr}$ and accounting for $70 \%$ of the 52250 volcano-related deaths during 1900 1982 (Blong, 1984). Their destructive nature also causes extensive building and vegetation damage due to impact, collapse, racking, burial, and ignition (Blong, 1984). In this regard, block-and-ash flows due to gravitational collapse of the Unzen lava dome (Japan) during 1990-1995 extended $>4 \mathrm{~km}$ from their source, causing 43 deaths and widespread destruction (Yamamoto et al., 1993; Fujii and Nakada, 1999; Ui et al., 1999).

Many workers have observed active 'a'a lava flows to understand their emplacement mechanisms (e.g., Pinkerton and Sparks,

GSA Bulletin; May 2002; v. 114; no. 5; p. 533-546; 10 figures; 2 tables. 
1976; Peterson and Tilling, 1980; Rowland and Walker, 1987; Kilburn and Guest, 1993). For block flows, however, workers have described features at inactive flows and drawn inferences regarding block-flow properties and mechanics from these observations (summaries in, e.g., Macdonald, 1972; Cas and Wright, 1987; Francis, 1993). In addition, observations of active flows at Arenal (Costa Rica) (Borgia et al., 1983; Cigolini et al., 1984; Borgia and Linneman, 1990) provide insights into the emplacement mechanisms and rheology of transitional 'a'a-block flows. However, although thermal measurements have been made on active dacitic lava domes by using airplane- and satellite-borne thermal sensors (e.g., Friedman et al., 1981; Oppenheimer et al., 1993; Wooster et al., 2000), detailed ground-based thermal and observational data for an active block flow during emplacement are extremely rare. Chief among the factors that contribute to the lack of observations of active block flows are unsafe access and the hazard posed by flow-front collapse. These preclude close approach and direct measurement.

During January 2000 we used a number of noncontact field- and satellite-based remotesensing approaches to obtain data for an active dacitic block flow at Santiaguito (Guatemala). During the course of our measurements, frequent and spatially random collapses of the flow front and marginal levees generated localized ash clouds. Although these extended just a few meters from the flow, their thermal infrared thermometer-derived temperatures of up to $185{ }^{\circ} \mathrm{C}$ showed that they would have been extremely hazardous to workers making contact measurements. Here we describe our observations of the morphology and thermal structure of the flow, where our ground-based measurements provide a rare insight into block-flow emplacement and cooling. We use our observations to (1) gain an insight into the thermal and rheological characteristics of an active block flow, (2) consider issues that determine flow-front stability and hence the probability of block-and-ash flow generation, (3) infer the manner in which such well-insulated flows cool and are emplaced, and (4) consider the problems encountered if interpreting remotely sensed thermal data for such cold, but active flows.

\section{ACTIVITY AND THERMAL MEASUREMENTS}

Rose (1987b) defined a three-phase history for the evolution of Santa Maria and Santiaguito. The first phase began at ca. $30000 \mathrm{yr}$

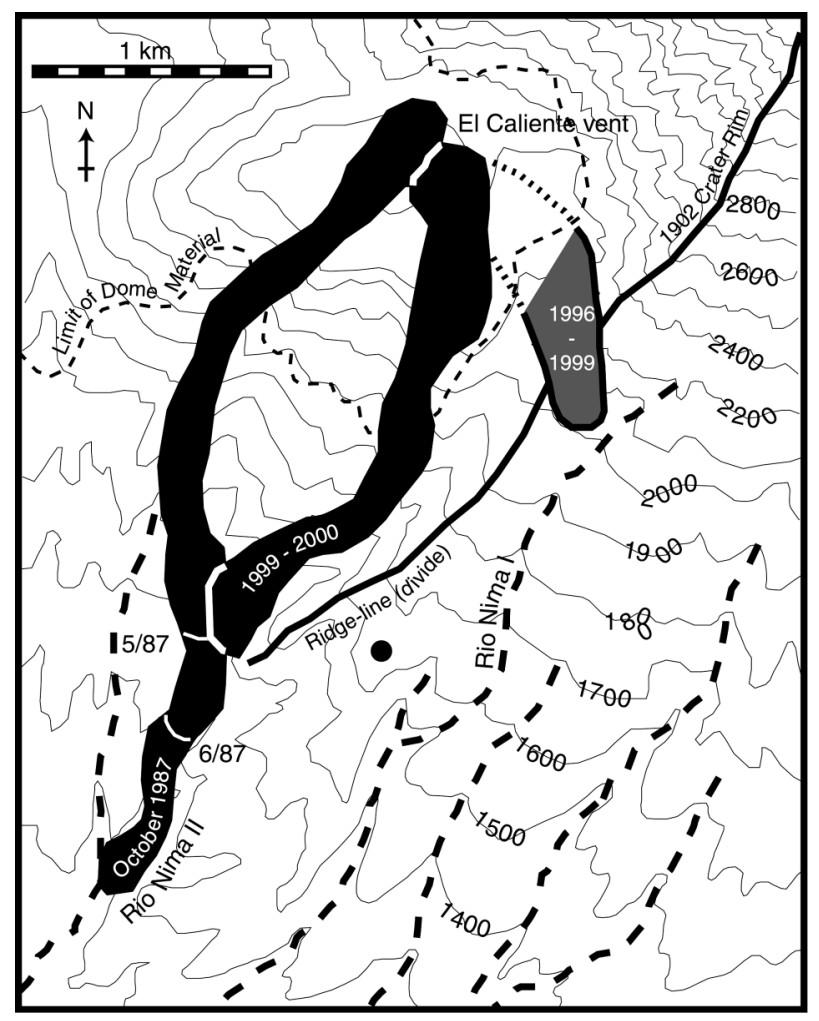

Figure 1. Topographic map of the El Caliente vent at Santiaguito, Guatemala. Block flows active at Santiaguito during 1987, 1996-1999, and 1999-2000 were mapped by using the Landsat data given in Figure 2. Thin white lines show positions of flow fronts during May and June 1987 according to details in SEAN (1988a, 1988b). Thick dashed lines indicate main rivers, and the solid circle marks the approximate location of our ground-based measurements in January 2000.

B.P. and involved the construction of the Santa Maria composite cone. This phase was characterized by an eruption rate of $\sim 1.1 \mathrm{~m}^{3} \cdot \mathrm{s}^{-1}$, with initial eruptions of basaltic lavas followed by a gradual transition to more silicic lavas. The second phase involved the Plinian eruption of 1902 during which $8.5 \mathrm{~km}^{3}$ of dense dacite and a minor proportion of basaltic andesite were erupted (Rose, 1987b; Williams and Self, 1983). The third phase has included the ongoing construction of the Santiaguito dome complex.

Activity at Santiaguito began in 1922 and has been characterized by continuous, slow $\left(\sim 0.4 \mathrm{~m}^{3} \cdot \mathrm{s}^{-1}\right)$ extrusion of dacite lava (Rose, 1972, 1987a). Persistent effusive activity from four distinct vents (El Caliente, La Mitad, El Monje, and El Brujo) has built an $\sim 1 \mathrm{~km}^{3}$ complex of overlapping domes and block flows centered within the 1902 crater. Since 1958 , activity has been characterized by an increasing prominence of block flow, as opposed to dome emplacement (Rose, 1987a). Harris et al. (2001) have noted that the length of individual block-flow units has increased through time, a possible result of a $2 \mathrm{wt} \%$ decrease in the $\mathrm{SiO}_{2}$ content of erupted products since 1970 and hence a reduction in the lava viscosity. The block flows at Santiaguito do not display well-developed polyhedral blocks, nor do the flows carry the spinose clinker typical of 'a'a. Instead, Santiaguito block-flow surfaces are composed of angular to rounded dacite blocks, similar in form to the rubblelike surfaces that cover the dome units within the complex.

The activity that we observed during January 2000 was fed by effusion from El Caliente, the most eastern vent. Activity at the vent consisted of small, nonexplosive exhalations of gas and ash at a rate of approximately two events per hour, a style of activity that has persisted at this vent since 1975 (Rose, 1987a). A low active dome rose $\sim 10 \mathrm{~m}$ above the vent rim, from which an active block-lava flow extended southward down the flank of the dome complex. At the base of the dome pile, the flow was deflected southwest by a low ridge, to attain a total length of $2370 \pm$ $90 \mathrm{~m}$ (Fig. 1). Ground-based observations in- 
dicate that extrusion of this flow began during July 1999; an increase in volcanic radiance recorded by the Geostationary Operational Environmental Satellite (GOES) satellite indicates that extrusion may have begun around July 14, giving a time-averaged advance rate of $12.5 \pm 1.5 \mathrm{~m} /$ day.

To make our field-based thermal measurements we used a Raytek Raynger 3i. This unit is a hand-held, noncontact thermal infrared (8-14 $\mu \mathrm{m})$ thermometer, with a response time of $0.7 \mathrm{~s}$. At the typical measurement distances of this study $(20,1000$, and $1500 \mathrm{~m})$, the Raytek will measure the temperature of 0.3-, 13-, and 20-m-wide surface areas. Measurements of the vent and proximal-medial flow sections were made vertically and obliquely from helicopter passes $\sim 1000 \mathrm{~m}$ above and to the south of the vent on January 21. On January 23 , ground-based measurements were made of the vent and proximal-medial flow sections from a ridge $\sim 1500 \mathrm{~m}$ to the south and of the flow front from a distance of $\sim 20 \mathrm{~m}$ (Fig. 1).

Field measurements commenced $\sim 6 \mathrm{~h}$ before, and continued through, the time of an overpass of the Landsat 7 satellite. Landsat 7 carries the Enhanced Thematic Mapper $(\mathrm{ETM}+)$, a multispectral instrument capable of providing 15-60 m spatial resolution data in eight wave bands (Fig. 2). Multicomponent mixture modeling of thermal data provided by $\mathrm{ETM}+$ bands $4(0.76-0.90 \mu \mathrm{m}), 5$ (1.55-1.75 $\mu \mathrm{m}), 6(10.42-11.42 \mu \mathrm{m})$, and $7(2.08-2.35$ $\mu \mathrm{m})$ allows the thermal structure of active lava surfaces to be determined (Flynn et al., 2000). All data were corrected for atmospheric effects by using a MODTRAN tropical atmospheric model. Emissivity corrections for $\mathrm{ETM}+$ bands 4,5 , and 7 were chosen by using reflectance spectra from a dacite lava sample. This approach gave an emissivity of 0.82 in all three bands. For the thermal infrared (Raytek and ETM+ band 6), we used the emissivity for andesite and rhyolite of 0.900.91 given by Salisbury and D'Aria (1992).

\section{MORPHOLOGIC, DIMENSIONAL, AND THERMAL OBSERVATIONS}

On the basis of our down-flow thermal observations, we divided the flow into three thermally distinguishable sections: proximal, medial-distal, and toe (Figs. 2 and 3). The proximal section is defined by relatively high surface temperatures $\left(T_{\text {surf }}\right)$ that show a consistent decline down section. The medial-distal section is characterized by relatively low $T_{\text {surf }}$ The toe section (which includes the flow front) is defined by an increase in $T_{\text {surf }}$, which rises to values similar to those obtained in the

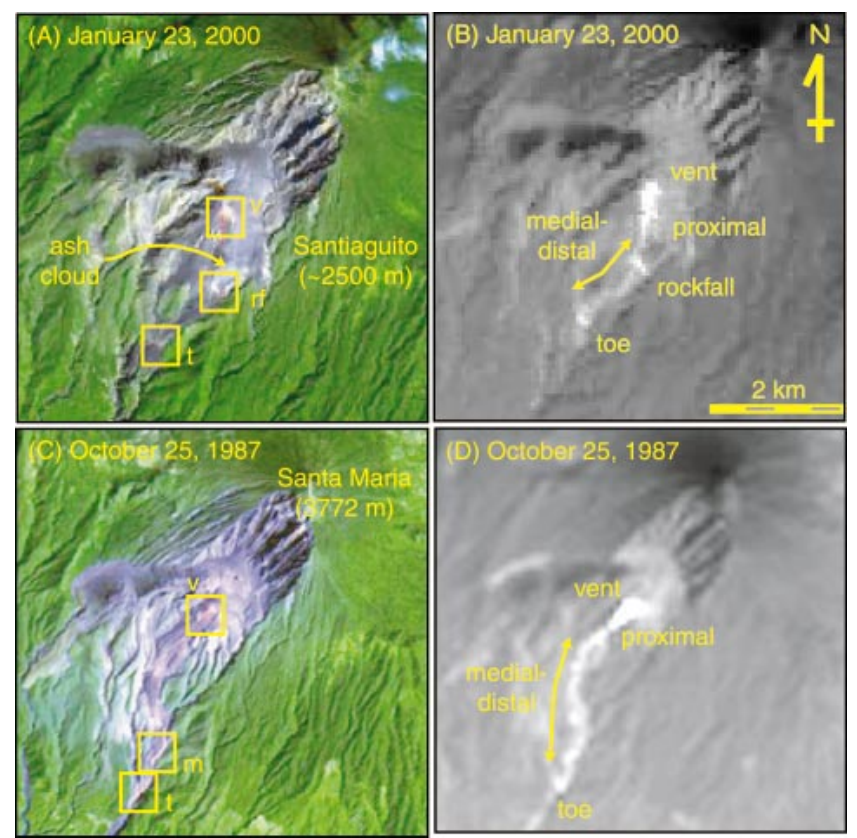

Figure 2. (A) Landsat 7 ETM+ short-wave infrared (SWIR) composite (bands 7, 5, 3) of the Santiaguito dome complex on January 23, 2000. The active vent, rockfall, and toe are located by boxes marked $v$, rf, and $t$, respectively. In this image the amphitheater resulting from the 1902 eruption of Santa Maria is clearly visible to the northeast of the dome complex. (B) Landsat 7 ETM+ thermal infrared (TIR) image (band 6) of the same area as A. (C) Landsat 5 Thematic Mapper SWIR composite of Santiaguito on October 25, 1987. The active vent, medial-distal section, and toe are located by boxes marked $\mathrm{v}, \mathrm{m}$, and t, respectively. (D) Landsat 5 Thematic Mapper TIR image of the same area as $C$. Note that there is no SWIR thermal emission from the active block flow beyond the $\mathrm{v}$, rf, and $t$ locations, and the band 6 anomaly is of a low magnitude.

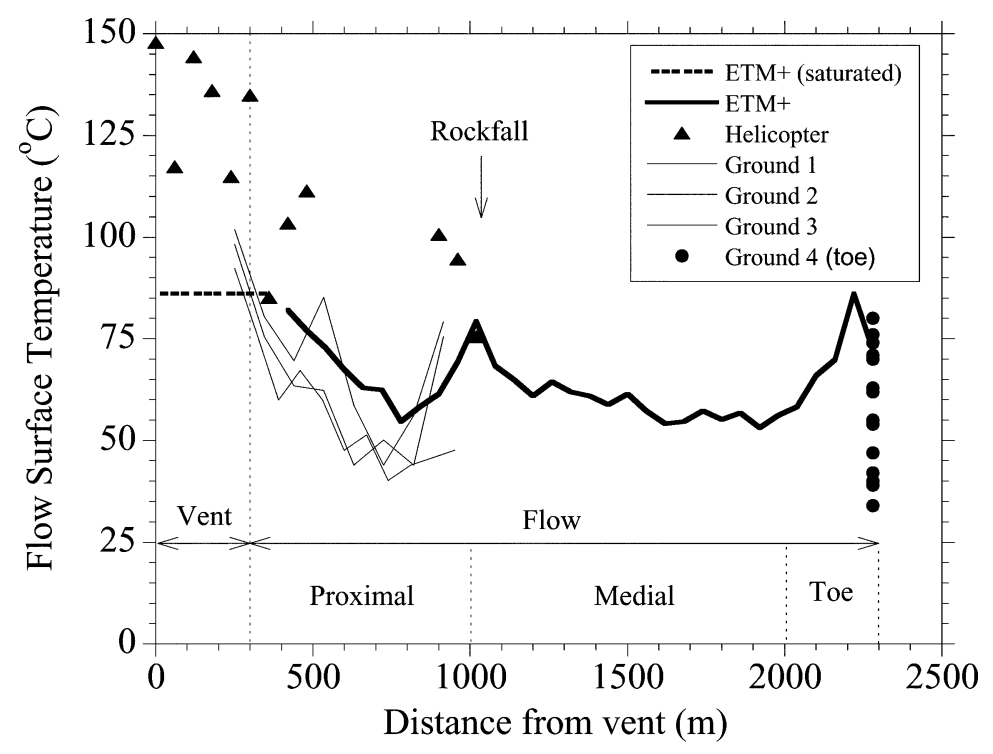

Figure 3. Down-flow surface-temperature profiles obtained for the 1999-2000 active block flow at Santiaguito from helicopter, ground-based, and ETM+ temperature measurements. 
proximal section. In addition, by exposing hotter core material, rockfall events generated by flow-margin collapse can cause localized thermal anomalies at any point along the flow.

\section{Proximal Flow Section}

The proximal section extends $\sim 700 \mathrm{~m}$ from the rim of the vent area southward down the steep $\left(\sim 30^{\circ}\right)$ slopes of the dome flank. Over this section the flow was $60-100$ $\mathrm{m}$ wide and covered with a continuous cooled crust of rubble $(10-100-\mathrm{cm}$-wide clasts) and larger (1-3-m-wide) blocks. At the dome base the flow was contained within an $\sim 40$-m-high embankment of rubble, resting at an angle of $\sim 30^{\circ}$, and the surface displayed well-developed surface folds. These flow dimensions and our estimate of the flow's time-averaged velocity $\left(1.45 \pm 0.17 \times 10^{-4}\right.$ $\mathrm{m} \cdot \mathrm{s}^{-1}$ ) yield an eruption rate of $0.475 \pm 0.165$ $\mathrm{m}^{3} \cdot \mathrm{s}^{-1}$. This rate is in excellent agreement with eruption rates of $0.48 \pm 0.09 \mathrm{~m}^{3} \cdot \mathrm{s}^{-1}$ calculated following the methodology of Harris et al. (1998).

Measured surface temperatures $\left(T_{\text {surf }}\right)$ were highest across this section of the flow, where $T_{\text {surf }}$ values of $76-111,40-85$, and $55-86{ }^{\circ} \mathrm{C}$ were obtained from the helicopter-, ground-, and ETM+-based measurements, respectively (Fig. 3). Down this section, surface temperatures showed a consistent decline at a rate of 0.04-0.09 ${ }^{\circ} \mathrm{C} \cdot \mathrm{m}^{-1}$, which, for a velocity of 1.3-1.6 $\times 10^{-4} \mathrm{~m} \cdot \mathrm{s}^{-1}$, converts to a surface cooling rate of $0.02-0.05{ }^{\circ} \mathrm{C} \cdot \mathrm{h}^{-1}$. Following Oppenheimer (1991) we use $T_{\text {surf }}$ to calculate radiative and convective heat losses $\left(Q_{\mathrm{rad}}\right.$ and $\left.Q_{\text {conv }}\right)$ and hence the thickness of the conductive boundary layer $(\delta)$. Assuming that all heat conducted across the flow's crust $\left(Q_{\text {cond }}\right)$ is lost from the surface by radiation and convection (i.e., $Q_{\text {cond }}=Q_{\text {rad }}+Q_{\text {conv }}$ ), $\delta$ can be calculated by rearranging Fourier's law of heat conduction (Holman, 1992) so that

$$
\delta=k\left(T_{\text {core }}-T_{\text {surf }}\right) / Q_{\text {cond }},
$$

where $k$ is thermal conductivity and $T_{\text {core }}$ is the flow's core temperature (Table 1). Over the entire length of the flow we calculate $\delta$ in the range of 1.9-3.3 m (Fig. 4). This result compares with observed crust thickness at the flow front of 2-10 m. Our calculated and observed $\delta$ values for this dacitic block flow are much higher than those obtained for active 'a'a flows and pahoehoe flows (Table 2).

Following Keszthelyi (1995) we calculated down-flow cooling of the core by using the flow's heat budget. In this case, by assuming that heat gained per unit length from latent
TABLE 1. DEFINITION OF TERMS, CONSTANTS, VARIABLES, ERRORS, AND SOURCES

\begin{tabular}{|c|c|c|c|}
\hline Term & Definition & Value (units) & Source \\
\hline$\alpha$ & Slope & $8.5^{\circ} \pm 5.5^{\circ}$ & Kimberly (1995) \\
\hline$A_{\text {cross }}$ & Flow cross-sectional area & Calculated $\left(\mathrm{m}^{2}\right)$ & $=d D$ \\
\hline$A_{\text {pixel }}^{\text {cross }}$ & Pixel area & $3600 \mathrm{~m}^{2}$ & ETM+ pixel area \\
\hline$\beta$ & Constant & 3 (for broad flows) & Cas and Wright (1987) \\
\hline$C_{P}$ & Specific heat capacity & $1150 \pm 250 \mathrm{~J} \cdot \mathrm{kg}^{-1} \cdot \mathrm{K}^{-1}$ & Bacon (1977) \\
\hline$\delta$ & Crust thickness & Calculated $(\mathrm{m})$ & Equation 1 \\
\hline$d$ & Flow depth & $\mathrm{P}: 30 \mathrm{~m} ; \mathrm{S}: 18 \mathrm{~m}$ & Field measured \\
\hline$D$ & Flow diameter & $P: 140 \mathrm{~m} ; \mathrm{S}: 30 \mathrm{~m}$ & Field measured \\
\hline$D_{h}$ & Flow hydraulic diameter & Calculated & $\begin{aligned}= & 4 A_{\text {cross }} / P(\text { Holman, 1992; Heslop et } \\
& \text { al., 1989) }\end{aligned}$ \\
\hline $\mathrm{D}_{y}$ & Strain rate at $y$ & Calculated $\left(\mathrm{s}^{-1}\right)$ & $=d v_{x y} / d y($ Cigolini et al., 1984) \\
\hline$\epsilon_{z}$ & Strain rate at $d=z$ & Calculated $\left(\mathrm{s}^{-1}\right)$ & Equation $\mathrm{A} 3$ \\
\hline$f$ & Friction factor & Calculated & $=K / \operatorname{Re}($ Heslop et al., 1989) \\
\hline$g$ & Gravitational acceleration & $9.8 \mathrm{~m} \cdot \mathrm{s}^{-2}$ & Constant \\
\hline$g_{\mathrm{c}}$ & Proportionality constant & 1.0 & Pitts and Sissom (1997) \\
\hline$\eta$ & Viscosity & Calculated $\left(\mathrm{N} \cdot \mathrm{s} \cdot \mathrm{m}^{-2}\right)$ & Equation A2 \\
\hline$\eta_{f}$ & Dynamic viscosity & Calculated $\left(\mathrm{N} \cdot \mathrm{s} \cdot \mathrm{m}^{-2}\right)$ & $=\rho \eta($ Pitts and Sissom, 1997) \\
\hline$h_{\mathrm{p}}$ & Plug flow height & P: 18 m; S: 10 m & Field estimated \\
\hline$\eta_{z y}$ & Viscosity at $y$ & Calculated & Equation A9 \\
\hline$K$ & Friction factor $K$ value & $30-60$ & Heslop et al. (1989) \\
\hline$k$ & Thermal conductivity & $2 \pm 1 \mathrm{~W} \cdot \mathrm{m}^{-1} \cdot \mathrm{K}^{-1}$ & $\begin{array}{l}\text { Robertson and Peck (1974), Giberti et } \\
\text { al. (1992), Kilburn (1993) }\end{array}$ \\
\hline$L$ & Flow length & $2370 \pm 90 \mathrm{~m}$ & January 23,2000, ETM+ image \\
\hline$n$ & Constant & 1 & Cas and Wright (1987) \\
\hline$P$ & Wetted perimeter & Calculated (m) & $=2 d+D$ \\
\hline$d p / d x$ & Pressure gradient & Calculated $\left(\mathrm{N} \cdot \mathrm{m}^{-2}\right)$ & Equation A6 \\
\hline$Q_{\text {cond }}$ & Conducted heat loss & Calculated $\left(\mathrm{J} \cdot \mathrm{S}^{-1}\right)^{\prime}$ & $=Q_{\mathrm{rad}}+Q_{\mathrm{conv}}$ \\
\hline$Q_{\text {conv }}$ & Convective heat loss & Calculated $\left(\mathrm{J} \cdot \mathrm{S}^{-1}\right)$ & Oppenheimer (1991) \\
\hline$Q_{\mathrm{rad}}$ & Radiative heat loss & Calculated $\left(\mathrm{J} \cdot \mathrm{s}^{-1}\right)$ & Oppenheimer (1991) \\
\hline$R$ & Flow radius & P: 70 m; S: 15 m & Field measured \\
\hline$\rho$ & Lava density & $2500 \pm 300 \mathrm{~kg} \cdot \mathrm{m}^{-3}$ & Murase and McBirney (1973) \\
\hline $\mathrm{Re}$ & Reynolds number & Calculated & Equation $A 7$ \\
\hline$r_{y}$ & Flow radius at $y$ & $\mathrm{P}: 0-70 \mathrm{~m} ; \mathrm{S}: 0-15 \mathrm{~m}$ & Field measured \\
\hline$t^{y}$ & Emplacement duration & $193 \pm 10$ days & Field-based and GOES images \\
\hline$\partial T / \partial x$ & Cooling rate & Calculated $\left(\mathrm{K} \cdot \mathrm{m}^{-1}\right)$ & Equation 2 \\
\hline$T_{\text {core }}$ & Core temperature & Calculated (K) & $=T_{\text {erupt }}-(\delta T / \delta x) x$ \\
\hline$T_{\text {erupt }}$ & Eruption temperature & $1123 \mathrm{~K}$ & Scaillet et al. (1998) \\
\hline$\tau_{\mathrm{o}}$ & Yield strength & $\sim 8 \times 10^{4} \mathrm{~N} \cdot \mathrm{m}^{-2}$ & Model-derived \\
\hline$T_{\text {surf }}$ & Surface temperature & Measured (K) & Field-measured \\
\hline$\tau_{z}$ & Shear stress at $d=z$ & Calculated $\left(\mathrm{N} \cdot \mathrm{m}^{-2}\right)$ & Equation A4 \\
\hline$\tau_{z y}$ & Shear stress at $y$ & Calculated $\left(\mathrm{N} \cdot \mathrm{m}^{-2}\right)$ & Equation A8 \\
\hline$v_{\max }$ & Maximum velocity & $1.45 \times 10^{-4} \mathrm{~m} \cdot \mathrm{s}^{-1}$ & $\approx V$ \\
\hline$v_{\text {mean }}$ & Mean velocity & Calculated $\left(\mathrm{m} \cdot \mathrm{s}^{-1}\right)$ & $\approx v_{\max } / 2$ \\
\hline$v_{x y}$ & Velocity at $y$ & Calculated $\left(\mathrm{m} \cdot \mathrm{s}^{-1}\right)$ & Equation A5 \\
\hline$v_{x z}$ & Velocity at depth $=z$ & Calculated $\left(\mathrm{m} \cdot \mathrm{s}^{-1}\right)$ & Equation $\mathrm{A} 1$ \\
\hline$V$ & Flow velocity & $1.45 \pm 0.17 \times 10^{-4} \mathrm{~m} \cdot \mathrm{s}^{-1}$ & $=L / t$ \\
\hline$y$ & Cross-flow distance & $\mathrm{P}:$ 0-140 m; S: 0-30 m & Field measured \\
\hline$z$ & Depth in z-direction & 0 to $d \mathrm{~m}$ & Field measured \\
\hline
\end{tabular}

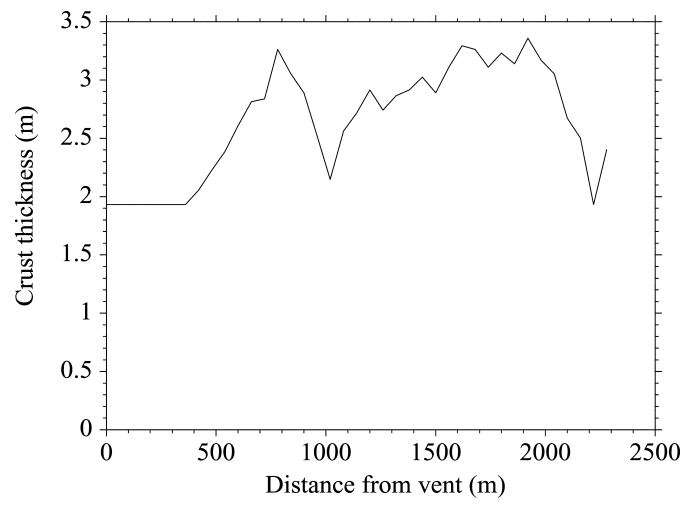

Figure 4. Down-flow profile of calculated crust thickness $(\delta)$. Crust thickness was calculated with equation 1 . 


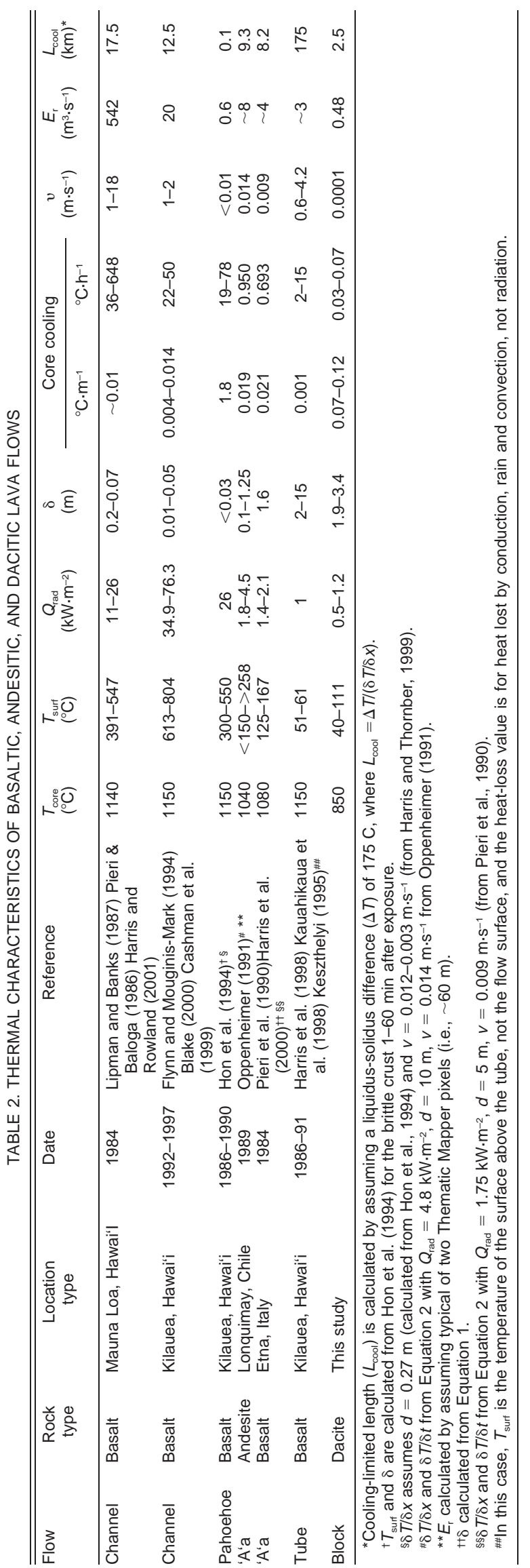

heat of crystallization is negligible and that all heat lost is accounted by $Q_{\text {cond }}$, the cooling rate in the down-flow direction $(\partial T / \partial x)$ can be calculated from

$$
\partial T / \partial x=\left(Q_{\text {cond }} / A_{\text {pixel }}\right) /\left(d V \rho C_{P}\right),
$$

where $A_{\text {pixel }}$ is pixel area, $d$ and $V$ are flow depth and velocity, respectively, $\rho$ is lava density and $C_{P}$ is lava specific heat capacity (Table 1). Over the proximal part of the flow we calculate core cooling rates of 57-158 ${ }^{\circ} \mathrm{C} \cdot \mathrm{km}^{-1}$, which converts to $0.028-0.091$ ${ }^{\circ} \mathrm{C} \cdot \mathrm{h}^{-1}$ (Fig. 5). These cooling rates are much lower that those calculated for ' $a$ 'a and pahoehoe flows (Table 2).

\section{Rockfall Events}

The proximal and medial flow sections are separated by a distinct peak in the temperature profile derived from ETM+ data (Fig. 3). We assume that this peak is due to a rockfall from the flow that occurred nearly simultaneously with the ETM+ acquisition. We infer this for three reasons: (1) the high frequency of rockfall events, (2) the size and orientation of the anomaly, and (3) association with a small ash cloud.

\section{(1) Rockfall Frequency}

During a 1-h-long observation period between 03:50 and 04:50 (all times are local) on January 23 , a total of 55 rockfall events were recorded, giving a rate of $\sim 1$ event per minute. Of these, 35 were generated by collapses from the dome or margins of the proximal flow section, 20 were generated by collapses at medial-distal and toe flow sections, and 7 caused small incandescent avalanches. The probability that such an event should be captured during the ETM+ overpass was therefore high.

\section{(2) Rockfall Size and Orientation}

Localized gravitational collapse of the flow margins fed rockfalls that tumbled down the steep flow levees, typically extending 50-400 $\mathrm{m}$ perpendicular to the flow direction. This configuration is consistent with the thermal anomaly derived from ETM+ data that is $\sim 150 \mathrm{~m}$ long and $30-60 \mathrm{~m}$ wide and is oriented away from the flow center line at an angle of $90^{\circ}$.

\section{(3) Rockfall-Generated Ash Clouds}

All rockfall events were associated with small ash clouds generated by abrasion of the tumbling blocks. These drifted a few hundred meters above and away from the rockfall. The 


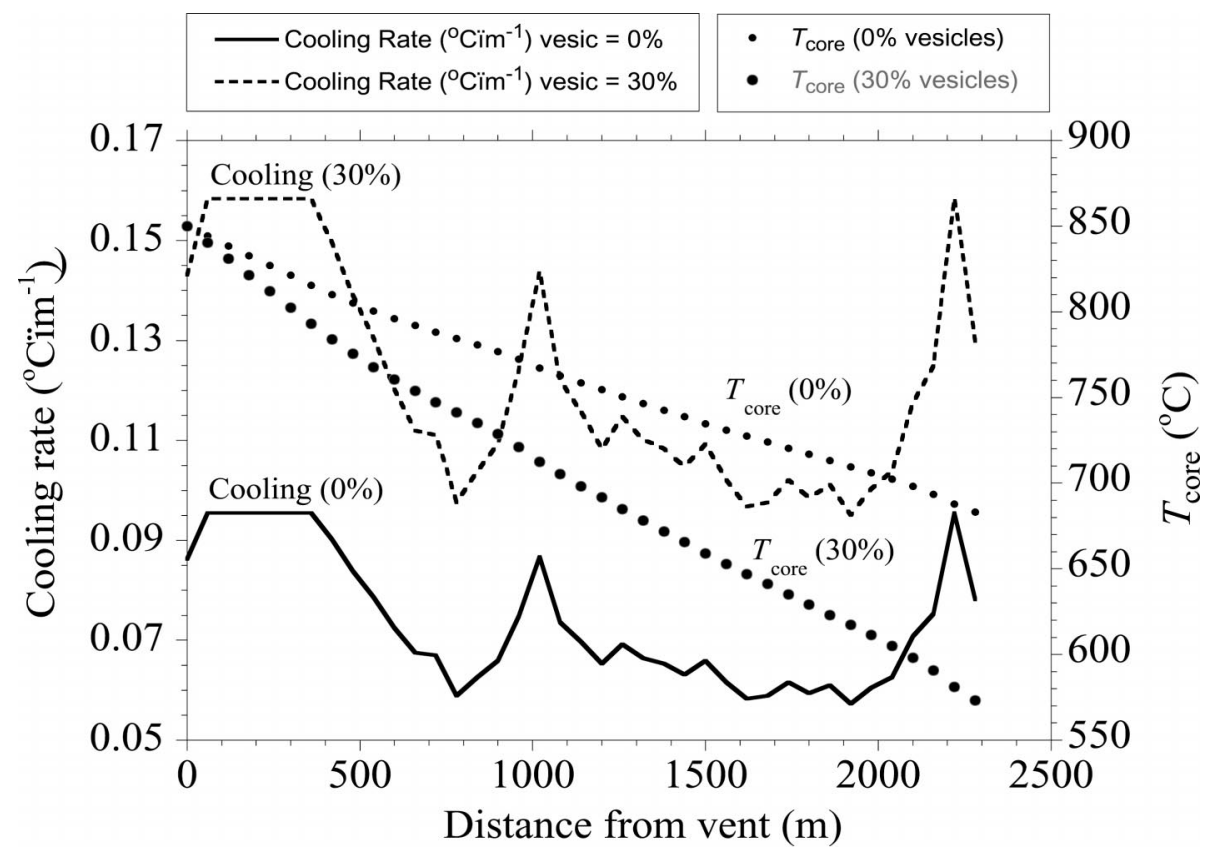

Figure 5. Down-flow profiles of calculated core cooling rates and core temperature $\left(T_{\text {core }}\right)$, calculated with equation 2. End-member curves for the cooling rate and $T_{\text {core }}$ assume no vesicles and $30 \%$ vesicles (Anderson et al., 1995), respectively, and an eruption temperature of $850{ }^{\circ} \mathrm{C}$ (Scaillet et al., 1998). Hence two curves are given for each parameter, one for calculations using $0 \%$ vesicles and a second using $30 \%$.

rockfall identified in the ETM+ image is the source of such a small $(1080 \times 210 \mathrm{~m})$ ash cloud.

Single-component thermal modeling (Rothery et al., 1988) for the ETM+ rockfall anomaly yields temperatures of $452-805{ }^{\circ} \mathrm{C}$. The upper range of this estimate compares with a calculated core temperature for this section of the flow of $710-780{ }^{\circ} \mathrm{C}$ (Fig. 5). This finding indicates that even small collapses involve crust and core material, but such localized exposure of the core seems insufficient to trigger a block-and-ash flow.

\section{Medial-Distal Flow Section}

The medial-distal section extends from the point at which the flow reaches the base of the dome and is deflected southwest by topography. This section was $\sim 1000 \mathrm{~m}$ long with a width of 180-210 m derived from ETM+ data. Shadows apparent on the ETM+ image indicated that a 30-90-m-wide channel zone was flanked by $30-60-\mathrm{m}$-wide levees. Given an angle of repose of $30^{\circ}$ for the levees, we obtain a levee height of 17-35 m, consistent with an observed flow-front thickness of 18$30 \mathrm{~m}$.

Surface temperatures across this section derived from ETM+ data were low $\left(53-64{ }^{\circ} \mathrm{C}\right)$ and showed a weak down-flow decline of 0.01
${ }^{\circ} \mathrm{C} \cdot \mathrm{m}^{-1}$ (Fig. 3). An identical trend of $0.01 \pm$ $0.02{ }^{\circ} \mathrm{C} \cdot \mathrm{m}^{-1}$ was obtained down four inactive flows adjacent to this section. This trend appears to be forced by an external cause rather than by lava cooling. Therefore we do not trust this trend to be volcanically significant. The cause may be increased shadowing with down-flow distance due to extension of the flows from the open slopes of the dome into shaded valleys. Most surface temperatures for the active flow, however, are elevated above the maximum obtained at any of the inactive flows by $25.7-0.5^{\circ} \mathrm{C}$. This elevation is due to heat conducted from the core of the active flow, where we calculate $\delta$ of 2.7-3.6 m (Fig. 4) and core cooling rates of $57-115^{\circ} \mathrm{C} \cdot \mathrm{km}^{-1}$ or $0.027-0.066{ }^{\circ} \mathrm{C} \cdot \mathrm{h}^{-1}$ (Fig. 5) for this flow section.

\section{Flow Toe}

Across this $\sim 300$-m-long flow section, the flow had a width of $\sim 200 \mathrm{~m}$ and a flow-front perimeter and height of $\sim 260 \mathrm{~m}$ and $18-30$ $\mathrm{m}$, respectively. The flow surface consisted of a blocky crust with temperatures of $34-80{ }^{\circ} \mathrm{C}$ and $56-86{ }^{\circ} \mathrm{C}$ derived from Raytek and $\mathrm{ETM}+$ data, respectively. The down-flow profiles show an increase in $T_{\text {surf }}$ across this flow section (Fig. 3) and a decrease in calculated $\delta$ to $1.9-3.2 \mathrm{~m}$ (Fig. 4). Thinner, hotter surface crusts are maintained by two processes: (1) avalanching of surface crust at the flow-front perimeter to expose hotter surfaces and (2) spreading and thinning the flow across the toe section. Elevated $\mathrm{T}_{\text {surf }}$ across this section results in an increase in $Q_{\text {cond }}$ and hence in the calculated rate of core cooling to 60-158 ${ }^{\circ} \mathrm{C} \cdot \mathrm{km}^{-1}$ or $0.028-0.091{ }^{\circ} \mathrm{C} \cdot \mathrm{h}^{-1}$ over this section (Fig. 5).

\section{Flow-Front Morphology and Processes}

Laterally, the flow front could be split into three segments on the basis of its morphologic and thermal characteristics: (1) an eastern marginal segment, (2) a medial-axial segment, and (3) a western marginal segment (Fig. 6A). Because access to the western marginal segment was impossible, here we describe our observations and interpretations of the eastern and medial segments.

\section{Marginal Segment of the Flow Front}

The eastern marginal segment was $\sim 60-\mathrm{m}$ wide and $\sim 18 \mathrm{~m}$ high. Across this segment the flow front consisted of blocks resting against the flow front at an angle of $32^{\circ}$. Vertically the flow front could be divided into three thermal zones, from top to bottom: A crust zone, midzone, and talus zone (Fig. 7). The flow was capped by a 2-3-m-thick blocky crust. This crust zone was composed of 1-3-m-wide, rounded to subangular blocks at temperatures of $34-76{ }^{\circ} \mathrm{C}$. The midzone consisted of an 8-10-m-thick layer of finer, hotter material; clasts were $<1 \mathrm{~m}$ wide, and temperatures were $56-142{ }^{\circ} \mathrm{C}$. A $2-5$-m-high basal talus zone was also dominated by larger (1-2-m-wide), cooler $\left(29-84{ }^{\circ} \mathrm{C}\right)$ blocks, thermally similar to the crust zone.

This structure was maintained by flow-front collapse (Fig. 7B). Collapses occurred once or twice per minute, affecting 2-5-m-wide sections of the flow front and generating small ash clouds at Raytek-derived temperatures of up to $185^{\circ} \mathrm{C}$. The source of all collapses was the crust zone and upper parts of the midzone. Higher temperatures at the midzone were maintained by repeated removal of surface material by the passage of collapse-fed avalanches; a temperature of $154{ }^{\circ} \mathrm{C}$ was obtained from a freshly exposed midzone surface immediately following a collapse. The similarity between the temperatures of the crust and talus zones results from the fact that the crust zone supplies material to the talus zone by collapse. Inclusion in the talus deposit of hotter material picked up from the midzone explains the slightly higher temperatures of the talus zone. 

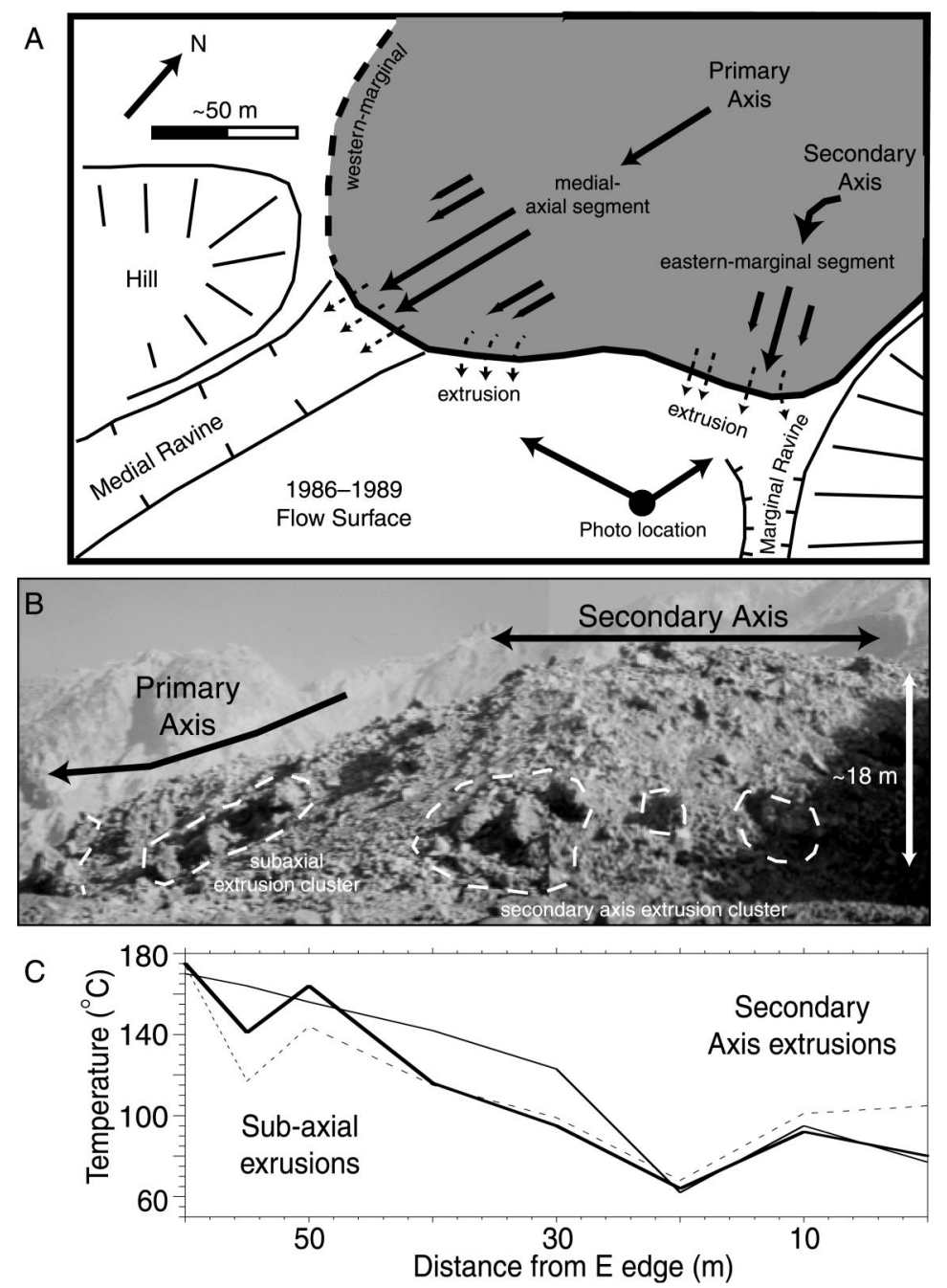

Figure 6. (A) Sketch map of the flow's toe section. Arrows at the head of solid lines indicate primary and secondary axes of advance, where arrow lengths are proportional to velocity (as calculated by using method in Appendix). The general location and orientation of extrusion clusters are also indicated (dashed lines). (B) Photograph of the eastern marginal segment of the flow front, looking toward the axial segment showing extrusion clusters (see A for photograph location). (C) Temperature profiles taken across of the eastern marginal segment of the flow front. Profiles were taken from west to east, i.e., from the flow axis to the margin, and were repeated three times to check for consistency. Peaks can be related to each extrusion cluster.

Clusters of massive, pink (oxidized) outcrops were common at the eastern and western edges of the marginal segment. These were associated with the most-forward-advanced parts of the flow front (Fig. 6). Each outcrop was $3-5 \mathrm{~m}$ wide, roughly circular to oval in cross section, showed crude radial jointing, and protruded 1-2 $\mathrm{m}$ outward from the flow front. During our observation period, one outcrop was truncated by a rockfall to reveal rooting of the extrusion back into the flow. All outcrops had higher temperatures (elevated by $6-96{ }^{\circ} \mathrm{C}$ ) than the surrounding blocky crust (Fig. 6C). We interpret these features to be terial from gathering on the flow front so that the frontal section of the flow core was exposed. The crust zone was therefore underlain by a core structure that was composed entirely of multiple, massive, roughly circular to oval extrusions with crude radial jointing (Fig. 8, $\mathrm{A}$ and $\mathrm{B}$ ). These were up to $10-\mathrm{m}$-wide and were similar in form to the extrusion features described at the eastern marginal flow-front segment. Across this zone, field-based temperatures of $157-303{ }^{\circ} \mathrm{C}$ were obtained; a peak of $496-531{ }^{\circ} \mathrm{C}$ was measured at a freshly exposed surface immediately following a flowfront collapse (Fig. 8, C and D). This freshsurface temperature compares with a core temperature near the flow front of $573-683{ }^{\circ} \mathrm{C}$ obtained from equations 1 and 2 by using an eruption temperature of $800-850{ }^{\circ} \mathrm{C}$ (Scaillet et al., 1998) and vesicularities of $0 \%-30 \%$ (Anderson et al., 1995). The high temperatures common to the core zone (Fig. 8) are consistent with this zone representing the exposed forward face of the flow core.

\section{MECHANICS OF BLOCK-FLOW ADVANCE}

Our observations support a model whereby forward motion is related to two simultaneous mechanisms: (1) flow-front oversteepening and collapse to cause caterpillar-track-type advance and pushing aside of frontal crust and (2) forward extrusion of the flow core through the frontal crust. To assess the validity of these mechanisms we have applied a model for a Bingham fluid exhibiting laminar plug flow (see Appendix). Horizontally, this model gives an $~ 59-m$-wide axial zone of plug flow (Fig. 9, A-C), consistent with a measured axialzone width of $\sim 50 \mathrm{~m}$. For this 30 -m-thick axial zone we obtain plug and shear-zone thicknesses of 18 and $12 \mathrm{~m}$, respectively, from the same model (Fig. 9, D and E).

Vertically, the plug dominates the top half of the flow, creating an upper high-velocity collapsing zone and a lower-velocity basal shear zone (Fig. 9, D and E). In this case, higher velocities at the flow top will result in oversteepening and subsequent instability and collapse of the upper zone. In the resulting caterpillar-track-type forward motion, material falling from the flow front is overridden by the advancing flow to contribute to a basal crust. This feature is typical of basaltic ' $a$ 'a flow emplacement (Wentworth and Macdonald, 1953; Macdonald, 1953, 1972; Cas and Wright, 1987; Kilburn and Guest, 1993) and also forms at transitional andesitic 'a'a-block flows, where identical flow-front structures 


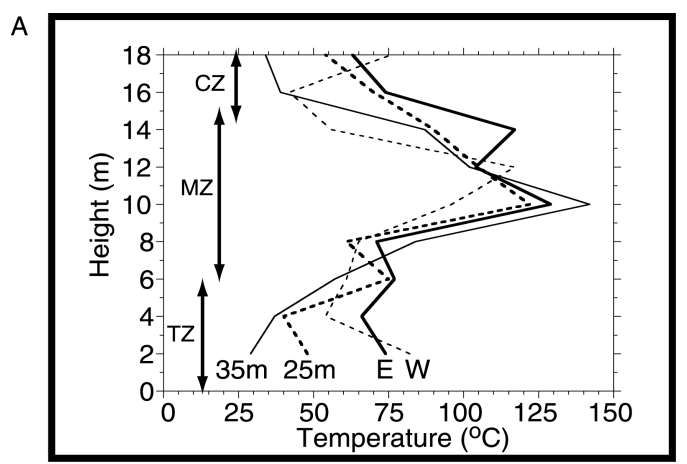

B

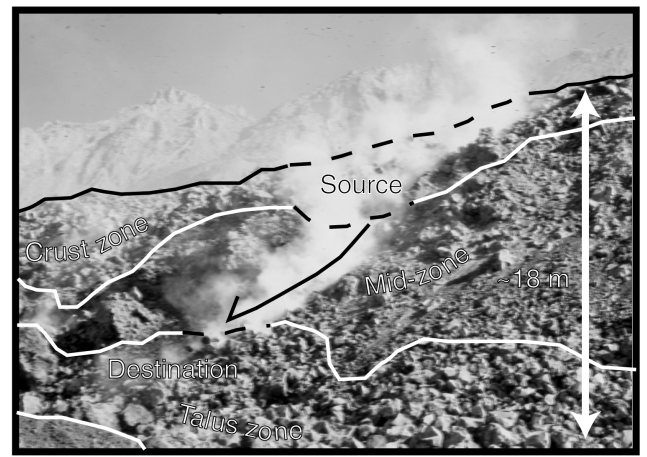

$\mathrm{C}$

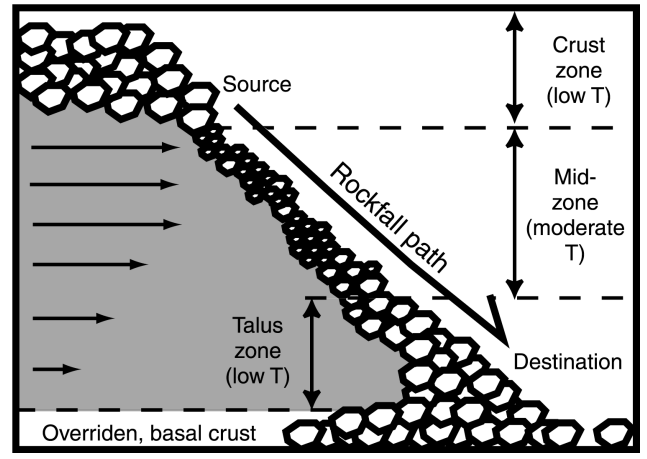

Figure 7. (A) Vertical temperature profiles (measurements taken approximately every 2 m) of the flow front taken at the eastern and western edges of the eastern marginal segment (lines marked $\mathrm{E}$ and $\mathrm{W}$, respectively) and 25 and $35 \mathrm{~m}$ along the flow front from the eastern edge (lines marked $25 \mathrm{~m}$ and $35 \mathrm{~m}$, respectively). The thermally defined positions of the crust, midzone, and talus zones are marked CZ, MZ, and TZ. (B) Photograph of the eastern marginal section of the flow front showing the location of three thermally defined zones and the source and destination of rockfalls. (C) Cartoon showing a cross section through the flow. Arrow lengths in block flow are proportional to velocity (as calculated by using method in Appendix).

develop (Cigolini et al., 1984; Borgia et al., 1983).

The extrusion features observed at the marginal and axial segments also support a flowemplacement model in which forward motion results in multiple toothpaste-like extrusions of the core through the frontal crust. Such toothpaste-like extrusions of viscous lava have been observed to pass through the crust at the toe of basaltic 'a'a flows in Hawai'i (Macdonald, 1953). Flow-front core extrusion has also been noted at basaltic andesite ' $a$ 'a flows fronts on Etna (Kilburn and Guest, 1993) and andesitic 'a'a-block flows at Arenal (Linneman and Borgia, 1993).

In the case considered here, extrusions are located at the primary and secondary axes of advance. Both of these axes occur where the flow is extending within or toward ravines (Fig. 6A). The resulting increase in slope, as well as flow confinement, at these locations will cause localized velocity increases, thus promoting shearing (Fig. 9A). Extrusions are also confined to the lower half of the flow (Fig. 6B), again a zone of high shear stress (Fig. 9E). Extrusion therefore appears to be due to squeeze out between shear planes. An extrusion cluster at the edge of, and extending obliquely from, the primary advance axis indicates that these structures may have their roots in a zone of divergent flow at the margin of the axial stream (Fig. 6). Such divergent flows at the margins of a central zone of plug flow have previously been observed at channelized 'a'a flows at Etna (Booth and Self, 1973).

\section{FLOW-FRONT STABILITY}

Block-and-ash flows can be generated by flow-front collapse followed by pore depressurization, vesiculation, and pulverization (Rose et al., 1976; Mellors et al., 1988; Fink and Manley, 1989; Fink, 1993; Fink and Kieffer, 1993; Fujii and Nakada, 1999; Ui et al., 1999). Once under way, a dense gravitational current avalanches along topographic lows, slowing with decreasing slope. Convection and fluidization, due to air heating and expansion and release of pore-stored gas during rock collisions, generates a fluidized, turbulent ash component that overrides and outruns the gravitational current (Mellors et al., 1988; Fink and Kieffer, 1993; Fujii and Nakada, 1999). We consider two interrelated trigger mechanisms for such flow-front collapse and block-and-ash flow generation: (1) gravitational flow-front collapse due to high underlying slopes and flow-front oversteepening and (2) exposure of overpressurized and/or volatile-rich core zones causing explosive decompression.

As shown by Voight and Elsworth (2000), increasing the angle of the failure plane $(\alpha)$ increases the forces acting to destabilize the flow, hence promoting collapse. Voight and Elsworth (2000) described stability in terms of the ratio of resisting to disturbing forces $\left(F_{\mathrm{s}}\right.$, where $F_{\mathrm{s}} \leq 1$ implies failure) and showed that such conditions are typically associated with $\alpha>20^{\circ}$. For the Santiaguito case, we calculate $F_{s}$ of 0.6 and 1.7 for flow fronts advancing over the $30^{\circ}$ and $10^{\circ}$ slopes characteristic of the proximal and distal flow sections, respectively. This result is consistent with our observation of seven small ( $\leq 300$-m-long) incandescent avalanches from the vent and proximal flow region during a 1-h-long period, but none from the distal section.

Flow-front oversteepening will also promote collapse. At Unzen (Japan), lower velocities at the flow base than in the upper zone caused oversteepening, with gravitational failure occurring where the overhanging angle reached $12^{\circ}$ (Yamamoto et al., 1993). This condition can be simulated by using the plug- 


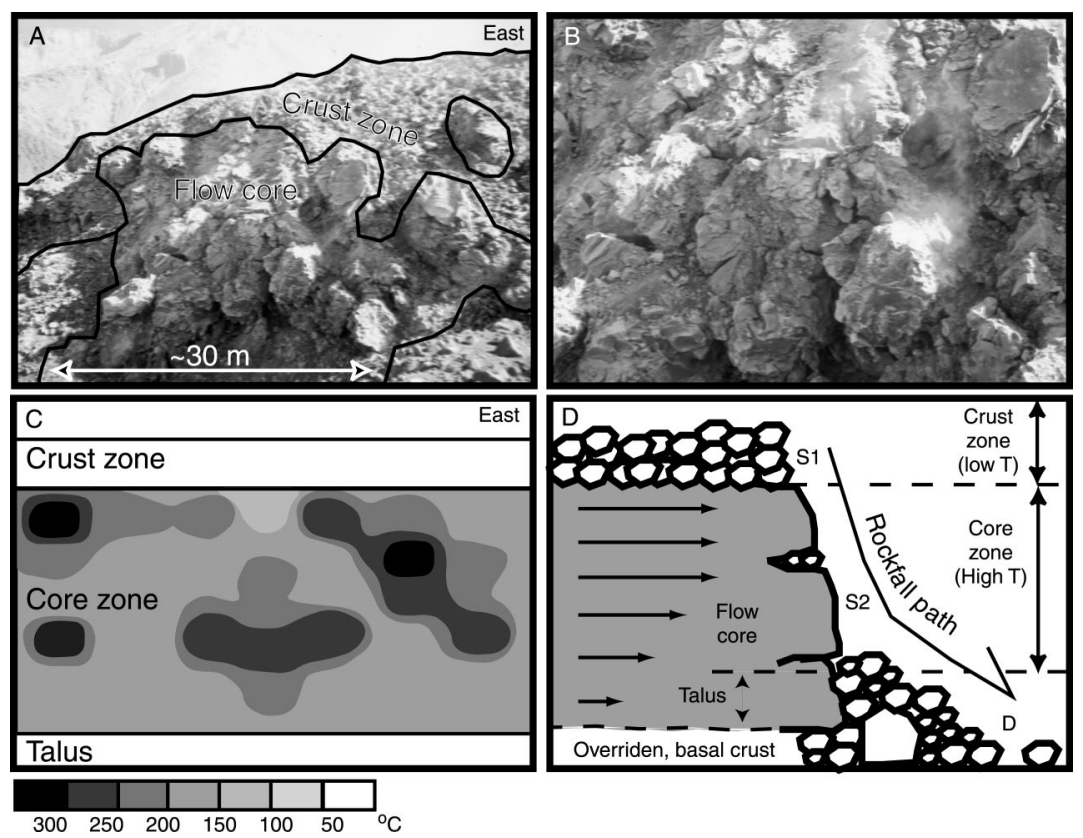

Figure 8. (A) Photograph of axial segment, showing frontal section of the flow core. The flow front of the western marginal section is visible at the extreme left of the photograph; the circle at the top right locates an extrusion through the crust zone. (B) Close up of a 15-20-m-wide section of the axial segment showing cross-section detail of forward-directed extrusion features. (C) Axial-segment temperature map. Contours are drawn by using temperature measurements taken across the area shown C. (D) Cartoon showing a cross section through the flow front. Arrow lengths in block flow are proportional to velocity (as calculated by using method in Appendix). Plug flow results in collapse of the upper flow front (between S1 and S2) to supply the talus zone (labeled D).

flow model (see Appendix). For Unzen, the measured flow thickness $(70 \mathrm{~m})$ and plug velocity $\left(4.2-9.2 \times 10^{-4} \mathrm{~m} \cdot \mathrm{s}^{-1}\right)$, with a plug thickness of $20 \mathrm{~m}$ (from Yamamoto et al., 1993; Fig. 5), gives a simulated basal zone velocity $(v)$ of $0.67-1.48 \times 10^{-4} \mathrm{~m} \cdot \mathrm{s}^{-1}$. This value compares with measured basal $v$ of 0.47-1.47 $\times 10^{-4} \mathrm{~m} \cdot \mathrm{s}^{-1}$ (Yamamoto et al., 1993). Given the critical oversteepening angle $\left(\sigma_{\text {crit }}\right)$ at which collapse occurs and flow depth $(d)$, the up-flow distance that collapse will effect $\left(L_{\text {crit }}\right)$ can be calculated from $\left[d \tan \left(\sigma_{\text {crit }}\right)\right]$, and the time taken for $\sigma_{\text {crit }}$ to be reached $\left(t_{\text {crit }}\right)$ from $[d / v]$. For Unzen, this gives $L_{\text {crit }}$ of $\sim 15$ $\mathrm{m}$ and $t_{\text {crit }}$ of $28-62 \mathrm{~h}$, which compares with a block-and-ash flow temporal frequency of one every 51-76 h (from Yamamoto et al., 1993).

If we apply the same model-based approach to the Santiaguito flow, we gain an insight into why the axial flow front is oversteepened. For the 30-m-thick axial plug flow zone, a 12-mhigh shear zone $\left(d_{\text {shear }}\right)$ has a velocity gradient $\left(\Delta v / \Delta d_{\text {shear }}\right)$ of $1.2 \times 10^{-5} \mathrm{~s}^{-1}$ (Fig. 9F). If collapse occurs at $\sigma_{\text {crit }}=12^{\circ}$, then we obtain $L_{\text {crit }}$ and $t_{\text {crit }}$ values of $\sim 6.3 \mathrm{~m}$ and $\sim 12 \mathrm{~h}$, respectively. In the marginal zone, the shear zone effectively comprises the entire $18 \mathrm{~m}$ flow thickness, and plug flow is absent so that $d_{\text {shear }}$ $=d$ (Fig. 9F). Across this zone, lower velocities (typically $v_{\max } / 2$, Fig. 9A) and higher $d_{\text {shear }}$ values result in lower $\Delta v / \Delta d_{\text {shear }}$ and $L_{\text {crit }}$ values and higher $t_{\text {crit }}$ values, these being $0.4 \times$ $10^{-5} \mathrm{~s}^{-1}, \sim 3.8 \mathrm{~m}$, and $\sim 15 \mathrm{~h}$, respectively. Therefore in the axial zone, higher-velocity gradients cause more frequent and more voluminous collapses than in the marginal zone, favoring a steeper flow front.

The difference in $v$ between the axis and margin suggests that the axis should overshoot the margins. That a greater volume of the axial flow front is being destroyed by collapse, however, serves to dampen the velocity difference. For example, we calculate that over a $60 \mathrm{~h}$ period, five collapses will occur at the axial zone and four will occur at the marginal zone. The resulting difference between advance (due to forward motion) and retreat (due to collapse) will be 0.5 and $0.46 \mathrm{~m}$ at the axis and margin, respectively.

In the two cases considered (Unzen and Santiaguito), flow-front collapse due to oversteepening generated block-and-ash flows only in the Unzen case. To trigger block-andash flow, the collapse must have a sufficient depressurization effect on the flow core. Ui et al. (1999) suggested that block-and-ash flows may be generated where flow-base pore pressure exceeds the lava tensile strength. Following their model, decreased tensile strength due to higher strain rate and shear stress at the flow base (Fig. 9E) will favor a situation where pore pressure can exceed the lava tensile strength during crack propagation or depressurization to cause explosive fragmentation. Fink and Manley (1989) also proposed a model where volatile concentration due to the migration and concentration of water vapor released during crystal growth and microfracturing increases the explosive hazard. During both cases, depressurization by flow-front collapse will trigger explosive decompression. We note that $L_{\text {crit }}$ calculated for Unzen and Santiaguito are $14.9 \mathrm{~m}$ and 3.8-6.4 m, respectively. Lower $L_{\text {crit }}$ at Santiaguito coupled with the lack of block-and-ash flow activity indicates that collapse involving low $L_{\text {crit }}$ values removes an insufficient proportion of the flow front to intersect overpressurized zones and is therefore less likely to generate block-and-ash flow.

Following these considerations we propose an integrated model for flow-front stability at Santiaguito. In this model, block-and-ash flows will most likely occur during advance down the steep slopes of the dome complex and/or during flow-front oversteepening at thick flow fronts exhibiting well-developed plug flow. Increases in the velocity gradient across the shear zone with increased flow thickness and velocity not only contribute to oversteepening, but also increase collapse frequency and the distance back from the flow front affected by collapse. The presence of these factors increases the likelihood that collapse will penetrate overpressurized and/or volatile-rich core zones behind the flow front, hence triggering block-and-ash flow.

Features of the September 16, 1973, blockand-ash flow at Santiaguito are consistent with this scenario. This event was triggered by collapse of a thick block-lava flow front that caused flow-core vesiculation such that vesicular particles constituted up to $50 \%$ of the block-and-ash flow deposit (Rose et al., 1976). Collapse occurred at the break of slope between the constructional topography of the dome apron and surrounding erosional topography (Sam Bonis, 2000, personal commun.). The increase in slope at this point would have caused a decrease in flow-front stability, as well as an increase in flow velocity. An aerial photograph (Fig. 8 in Rose et al., 1976) also shows that the flow was entering a narrow box canyon, as was the case for the axial zone con- 

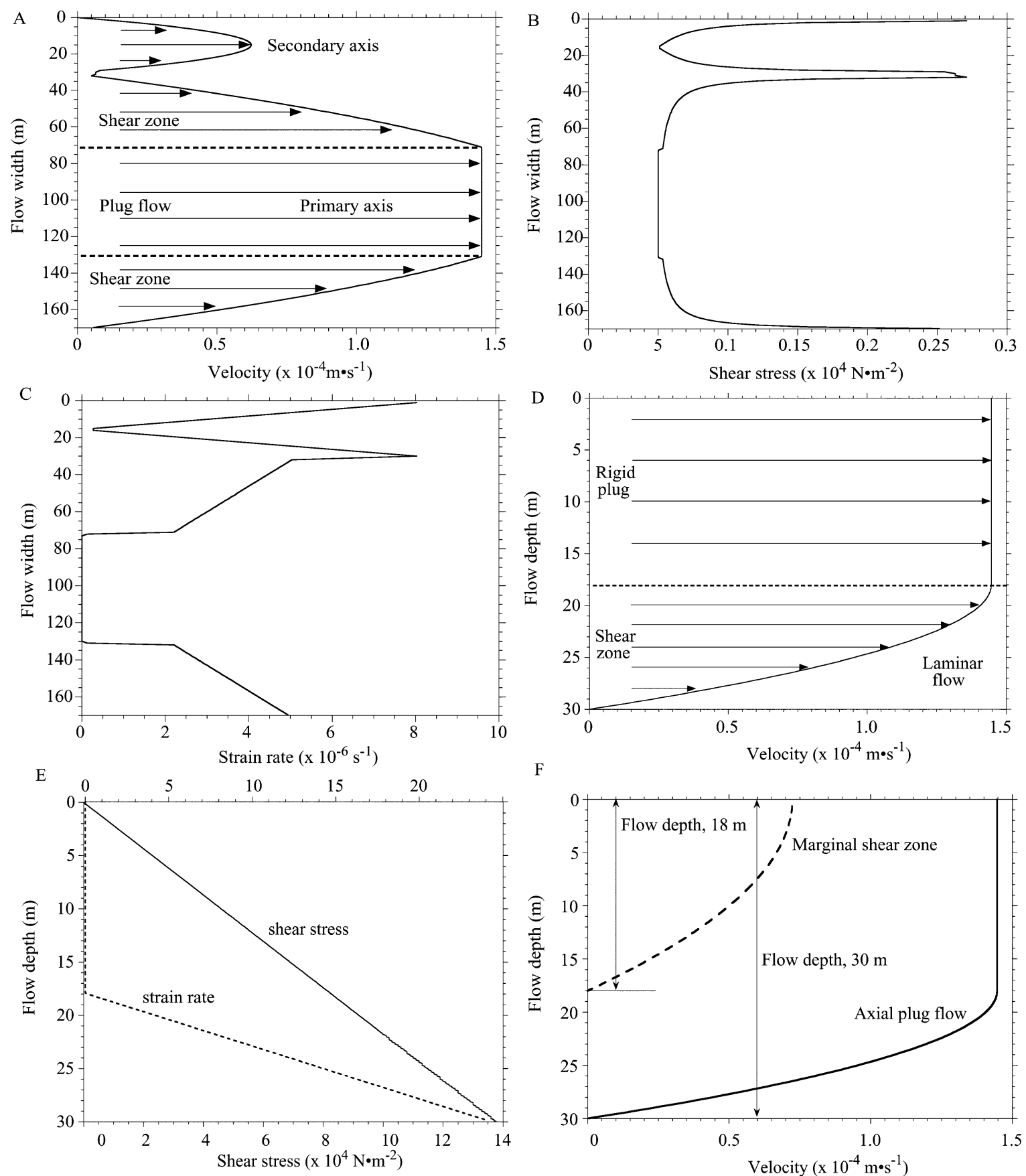

Figure 9. Calculated (A) cross-flow velocity, (B) shear stress, and (C) strain rate. Calculated (D) flow velocity and (E) shear-stress and strain-rate profiles in the axial zone of plug flow. Parameters are calculated from the model in the Appendix by using primary and secondary axis widths of $30 \mathrm{~m}$ and $140 \mathrm{~m}$ and assuming a flow thickness of $30 \mathrm{~m}$. (F) Comparison of the flow-velocity profiles are calculated by using the Appendix for the 18-m-high marginal shear zone and the 30-m-high axial plug-flow zone.

sidered here. Increased velocity caused by extension into a confining canyon and onto steeper slopes would have resulted in increased $\Delta v / \Delta d_{\text {shear, }}$, decreased $t_{\text {crit }}$, and, more important, increased $L_{\text {crit }}$ to levels sufficient to intersect the overpressurized, volatile-rich core zones.

\section{RHEOLOGICAL PROPERTIES}

We have used the plug-flow model detailed in the Appendix to simulate the rheological properties of this flow. Owing to the extremely low velocity of this flow, calculated strain rates are low, giving $1.2 \pm 0.5 \times 10^{-5} \mathrm{~s}^{-1}$ and
$2.5 \pm 2.2 \times 10^{-6} \mathrm{~s}^{-1}$ in the $z$ and $y$ flow directions, respectively (Fig. 9). Calculated shear stress and viscosities (Appendix) are, however, much higher at $6.7-8.5 \times 10^{4} \mathrm{~N} \cdot \mathrm{m}^{-2}$ and $0.4-2.6 \times 10^{10} \mathrm{~Pa} \cdot \mathrm{s}$, respectively. These viscosities are consistent with the $10^{8}-10^{9} \mathrm{~Pa} \cdot \mathrm{s}$ value given for rhyolite and andesite at 800 
$1000{ }^{\circ} \mathrm{C}$ by Murase and McBirney (1973) and with $5 \times 10^{11} \mathrm{~Pa} \cdot \mathrm{s}$ calculated following Shaw (1969) using cooling of $100{ }^{\circ} \mathrm{C}$ and a liquidus viscosity of $1000 \mathrm{~Pa} \cdot \mathrm{s}$ (Murase and McBirney, 1973). These high model-derived values explain the extremely low velocities encountered at this block flow, in spite of the $10^{\circ}-30^{\circ}$ slopes that the flow is advancing over. To place these values in context, we can compare this dacitic case with a basaltic case. Typical basaltic shear stresses and viscosities are much lower: $220-370 \mathrm{~N} \cdot \mathrm{m}^{-2}$ and $9400-10^{5}$ $\mathrm{Pa} \cdot \mathrm{s}$, respectively (Pinkerton and Sparks, 1978; Moore, 1987). Given these lower values, the same flow would advance at speeds of $5-59 \mathrm{~m} \cdot \mathrm{s}^{-1}$ if it were basaltic (calculated following Dragoni, 1993).

\section{DISCUSSION AND CONCLUSIONS}

\section{Flow Insulation and Hazard Implications}

Insulation by a thick crust means that block flows can extend surprising distances in spite of low eruption rates and forward velocities. Insulation serves to reduce surface temperature and heat loss so that core cooling rates are extremely low (Table 2). Given these cooling rates and a difference between liquidus and solidus of $150-200{ }^{\circ} \mathrm{C}$ (Archambault and Tanguy, 1976), we calculate that the blockflow core of this Santiaguito flow will take 89-278 days to cool to solidus. Assuming that flow movement will continue as long as the core temperature is above the solidus gives a cooling-limited flow length of 1.3-2.9 km, in spite of an eruption rate and velocity of $\sim 0.475 \mathrm{~m}^{3} \cdot \mathrm{s}^{-1}$ and $\sim 0.000145 \mathrm{~m} \cdot \mathrm{s}^{-1}$, respectively. Increasing flow depth and velocity retards the cooling rate (equation 2) such that, for a 70-m-thick flow with $v$ of 4.2-9.2 $\times$ $10^{-4} \mathrm{~m} \cdot \mathrm{s}^{-1}$, the cooling rate is $0.004-0.020$ ${ }^{\circ} \mathrm{C} \cdot \mathrm{m}^{-1}$ or $0.015-0.030{ }^{\circ} \mathrm{C} \cdot \mathrm{h}^{-1}$. This range of cooling rates yields a cooling-limited length of $7-50 \mathrm{~km}$.

These low cooling rates show that block flows are one of the most insulated forms of lava-flow emplacement, where the thick, cool, crusted carapace is an extremely efficient insulator. In Table 2 we have compared the heatloss characteristics of a variety of flow types. Channelized basaltic lava flows are thermally the most inefficient flow type, where thin, hot, discontinuous crusts result in high heat-loss rates and hence rapid core cooling. As a result, channelized flows are only able to extend tens of kilometers by virtue of rapid emplacement, i.e., high velocities and eruption rates (Keszthelyi and Self, 1998). As crusts become thicker, cooler, and more coherent, heat loss and hence flow cooling decreases (Table 2). Flow confined to a lava tube is thus a thermally efficient flow type, allowing even, loweffusion-rate flow to extend tens to hundreds of kilometers before cooling forces the flow to halt (Keszthelyi, 1995; Keszthelyi and Self, 1998). Table 2 shows that block flows have many thermal similarities with tube-confined flow, where the thick, cool crust insulates the flow, causing low heat losses and the lowest cooling rates for all flow types considered. As a result, a block flow has the capability of extending many kilometers at extremely low effusion rates and velocities before cooling forces stagnation. This conclusion is in agreement with Manley (1992, p. 27) who stated that "a common misconception about rhyolite lava flows is that they cannot advance far from their vents and are constrained to be small due to their high viscosities." Manley's (1992) model-based results and field studies of Obsidian Dome (California) show that slow cooling of 100-300-m-thick units mean that such flows could remain active for decades, even though advancing at extremely low velocities $\left(0.59-2.5 \mathrm{~km} \cdot \mathrm{yr}^{-1}\right)$.

The potential of a block flow to extend many kilometers has serious implications for the hazard posed to down-flow communities. As the block-flow front moves away from the vent, so the source of block-and-ash flows due to flow-front collapse extends closer to vulnerable communities. In the case of Santiaguito, the September 1973 block-and-ash flow issued from the lobe of a thick block flow $2 \mathrm{~km}$ from the El Brujo vent (Rose et al., 1976). The block-and-ash flow extended a further $3 \mathrm{~km}$ down valley, where the high temperature and "hurricane force" of the flow completely destroyed all vegetation and left a deposit that was up to $5 \mathrm{~m}$ thick and contained 4-m-diameter blocks (Rose et al., 1976). A block flow advancing $6 \mathrm{~km}$ from the El Caliente vent would place the flow front in the vicinity of the towns of El Palmar and San Felipe and within a region of extensive banana and coffee plantations. Such a flow would also move the block-and-ash flow source to within 10-15 km of the major population centers of San Sebastian and Retalhuleu, as well as the the PanAmerican Highway. Given block-and-ash flow velocities of $15-25 \mathrm{~m} \cdot \mathrm{s}^{-1}$ (Yamamoto et al., 1993), these communities would be affected within 7-17 min of a flow-front collapse. Such an event would have devastating effects. In this regard, the 1929 block-and-ash flow at Santiaguito traveled $\sim 10 \mathrm{~km}$ from the El Caliente vent, devastated several villages and plantations (including the region around El Palmar), and resulted in hundreds, possibly thousands, of fatalities (Rose, 1987a; Simkin and Siebert, 1994).

\section{Satellite-Based Thermal Detection}

Insulated emplacement is strikingly evident from the extremely low surface temperatures obtained for this active block flow. Along the entire flow length, our data based on helicopter, ground, and ETM + measurements gave $T_{\text {surf }}$ of $76-111^{\circ} \mathrm{C}, 34-85{ }^{\circ} \mathrm{C}$, and $53-86{ }^{\circ} \mathrm{C}$, respectively. Nighttime observations showed that there were no incandescent cracks anywhere on the flow. Extremely low velocities and a lack of thermal renewal of the flow surface means that the surface crust can exist for tens to hundreds of days, thus allowing time for significant cooling. Figures 3 and 4 show that at $\sim 750 \mathrm{~m}$ from the vent, the surface had cooled to a relatively stable $\sim 65^{\circ} \mathrm{C}$, and the crust had thickened to $3.3 \mathrm{~m}$. Given the velocity of this flow, this distance translates to a flow-surface age of 50-70 days.

With the exception of the vent region, low surface temperatures mean that most of the flow is invisible in the ETM+ short-wave infrared (SWIR) bands (Fig. 2). To emit detectable thermal radiation in the SWIR bands of ETM+, surfaces of $>900 \mathrm{~m}^{2}$ in area must attain temperatures of $>120{ }^{\circ} \mathrm{C}$ (Flynn et al., 2001). The lack of incandescent cracks and the low crust temperatures mean that the flow surface has failed to attain this level and was thus invisible in the SWIR bands (Fig. 2). Without ground validation, the rockfall half way down the flow could easily have been mistaken for the thermal signature from a collapsing flow front. A further $1.3 \mathrm{~km}$ down flow from the rockfall, the flow front itself is in fact an extremely subtle thermal anomaly in the SWIR data (Fig. 2). Such an anomaly would have been extremely difficult to identify with confidence in the SWIR data without the insights gained from our field work.

In contrast, surface temperatures derived from the thermal infrared (TIR) are elevated above those encountered at surrounding inactive flows. This is especially true across the distal section, as well as at the rockfall location and flow toe (Fig. 10). However, the magnitude of the thermal anomaly over other sections of the flow is not large. This is especially true of the medial-distal flow sections in the January 2000 image. In this case, across the section between 1100 and $2100 \mathrm{~m}$ from the vent, band 6-derived $T_{\text {surf }}$ values are in the range $53-65{ }^{\circ} \mathrm{C}$. This range compares with $40-58{ }^{\circ} \mathrm{C}$ at nearby inactive flows (Fig. 10) and makes this section of the flow difficult to 


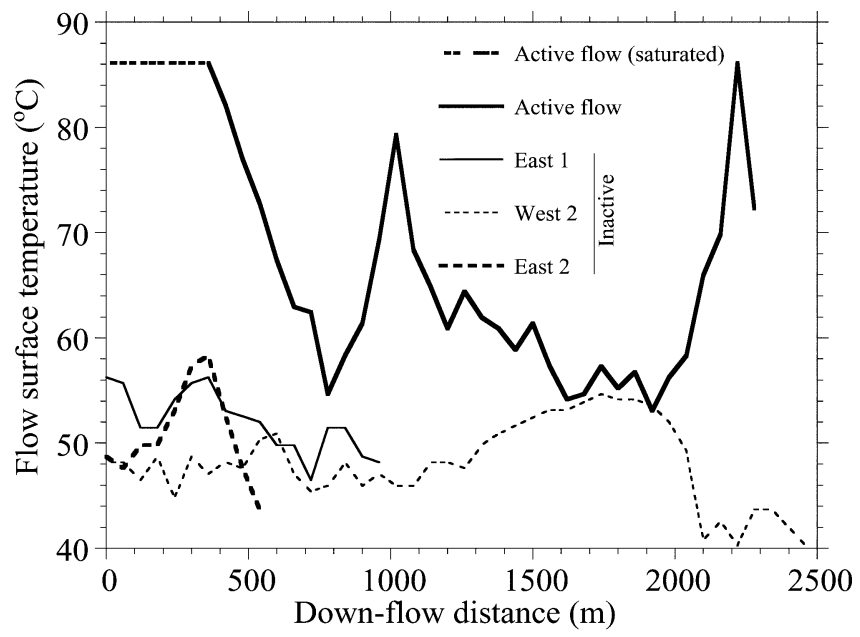

Figure 10. ETM+ derived down-flow surface-temperature profiles for the active flow and three inactive solar-heated flows with approximately the same aspect and altitudinal range as the active flow.

distinguish from the solar-heated background (Fig. 2B).

Other Thematic Mapper (TM) images of block flows at Santiaguito acquired on October 25, 1987, and February 14, 1988, show identical thermal structures. In both cases, the active, 3.6-km-long, block flow, although evident as a low-magnitude TIR anomaly, is invisible in the SWIR data except for a localized thermal anomaly at the vent and a subtle thermal anomaly at the flow toe (Fig. 2, C and D). The recurrence of these features leads us to suggest that low-magnitude TIR anomalies with subtle SWIR anomalies at their distal ends are diagnostic of block-flow activity in satellite thermal data. This correlation also argues for the need to examine TIR as well as SWIR data when locating and analyzing active block flows. Such data are currently available from Landsat ETM+ and the Advanced Spaceborne Thermal Emission and Reflection Radiometer (ASTER) flown on the Terra satellite (Yamaguchi et al., 1998; Ramsey et al., 2001).

\section{Thermal Stealth: A Feature of Block-flow Emplacement}

During May and June 1987, block flows at Santiaguito extended 2.5 and $2.9 \mathrm{~km}$, respectively (SEAN, 1988a, 1988b). A TM image acquired during October 1987 reveals extension to $3.6 \mathrm{~km}$ (Fig. 1), giving a time-averaged velocity and TM-derived eruption rate of 5$13 \mathrm{~m} / \mathrm{d}$ and $0.72 \pm 0.08 \mathrm{~m}^{3} \cdot \mathrm{s}^{-1}$ (Harris et al., 2001). These low rates of advance and eruption rate are comparable with those obtained for the January 2000 block flow, as are the image-derived $T_{\text {surf }}$ of $33-79{ }^{\circ} \mathrm{C}$ and calculated $\delta, \delta T / \delta x$, and $\delta T / \delta t$ of $2.2-4.9 \mathrm{~m}, 0.04-0.14$ ${ }^{\circ} \mathrm{C} \cdot \mathrm{m}^{-1}$ and $0.012-0.082{ }^{\circ} \mathrm{C} \cdot \mathrm{h}^{-1}$, respectively (compare with Table 2). We therefore suggest that such block flows represent a form of insulated emplacement, where thick crusts result in low core cooling rates and surface temperatures.

Block flows thus exhibit stealthy behavior, their activity and advance disguised by imperceptibly slow forward motion and extremely low surface temperatures. Johnson et al. (1995) used the term "stealth plume" to describe gaseous $\mathrm{SO}_{2}$ plumes on Io that would have been invisible to the remote-sensing instruments on the Voyager spacecraft. In the same way, Santiaguito's block flows are mostly invisible to the SWIR bands of terrestrial thermal remote-sensing instruments. In this case, the absence of strong SWIR emission typically associated with active lava flows, lakes, and domes (e.g., Rothery et al., 1988; Oppenheimer et al., 1993; Wooster and Rothery, 1997) would have caused this thermally stealthy flow to be overlooked.

\section{APPENDIX}

We calculate rheological parameters assuming that the lava behaves as a Bingham fluid and exhibits laminar flow. In this case, plug flow will occur where "the central part of the flow behaves as a relatively rigid plug, carried along by the flow as if it were a solid body" (Peterson and Tilling, 1980). Across the plug, velocity is constant and thus strain rates are zero (Gauthier, 1973; Williams and McBirney, 1979; Moore, 1987). Following Cigolini et al. (1984), flow velocity at depth $z\left(v_{x z}\right)$ is calculated (within the limits $v_{x z}=0$ at $z=d$ and $v_{x z}=v_{\max }$ at $\left.z=h_{\mathrm{p}}\right)$ from

$$
\begin{aligned}
v_{x z}=\rho g \sin (\alpha) d^{2} / & (2 \eta)\{1 \\
& \left.-\left[a^{2}+2 h_{\mathrm{p}}(d-z)\right] / d^{2}\right\}
\end{aligned}
$$

and, for $z=h_{\mathrm{p}}$,

$$
\eta=\rho g \sin (\alpha)\left(d-h_{\mathrm{p}}\right)^{2} /\left(2 v_{\max }\right),
$$

where $\eta, \rho, \mathrm{g}, \alpha, d, h_{\mathrm{p}}, z$, and $v_{\max }$ are lava viscosity, density, acceleration due to gravity, slope, flow depth, plug-flow height, depth on the z-axis (downward and perpendicular to the flow direction), and maximum forward velocity, respectively. Strain rate at depth $z\left(\varepsilon_{z}\right)$ is then calculated (according to Cigolini et al., 1984) by using the velocity gradient $\left(d v_{x z} / d z\right)$, where

$$
\varepsilon_{z}=d v_{x z} / d z
$$

and shear stress $\left(\tau_{z}\right)$ is calculated from

$$
\tau_{z}=\rho g \sin (\alpha) z
$$

Following, for example, Holman (1992), we calculate the flow-velocity profile in the cross-flow $(y)$ direction $\left(v_{x y}\right)$ within the limits $v_{x y}=0$ at $r_{y}=R$ and $v_{x y}=v_{\max }$ at $r_{y}=r_{\mathrm{p}}\left(r_{\mathrm{p}}\right.$ being the plug-flow radius) from

$$
v_{x y}=-\left(1 / 4 \eta_{\mathrm{f}}\right)(d p / d x)\left(R^{2}-r_{y}^{2}\right)
$$

where $\eta_{\mathrm{f}}, R$, and $r_{y}$ are dynamic viscosity, channel radius, and radius at cross-flow position $y$, respectively. Pressure decrease in the down-flow direction in a noncircular duct (Pitts and Sissom, 1997) $(\mathrm{dp} /$ $d x$ ) is obtained from

$$
-d p / d x=\left(f / D_{\mathrm{h}}\right)\left(\rho v_{\text {mean }}^{2} / 2 g_{\mathrm{c}}\right)
$$

where $f, D_{\mathrm{h}}, V$, and $g_{\mathrm{c}}$ are the friction factor, flow hydraulic diameter, mean velocity $\left(v_{\max } / 2\right)$, and proportionality constant (1.0), respectively. The hydraulic diameter is defined by $D_{\mathrm{h}} \equiv 4 A_{\text {cross }} / P$, where $A_{\text {cross }}$ and $P$ are flow cross-sectional area and wetted perimeter, respectively (Heslop et al., 1989; Pitts and Sissom, 1997). Friction factor is obtained from $f=K / \operatorname{Re}$ (Heslop et al., 1989), where $K$ is a constant dependent on channel shape (where we use $K$ $=30$ because we assume laminar flow in a roughbottomed channel) and $\mathrm{Re}$ is the Reynolds number (Pitts and Sissom, 1997; Heslop et al., 1989),

$$
\operatorname{Re}=\left(\rho v_{\text {mean }}^{2} D_{\mathrm{h}}^{2}\right) /\left(D_{\mathrm{h}} v_{\text {mean }} \eta_{\mathrm{f}}\right)
$$

In the cross-flow direction, strain rate $\left(\varepsilon_{y}\right)=d v_{x y}$ / $d y$, and we calculate shear stress as a function of flow depth and width $\left(\tau_{z y}\right)$ from (Cas and Wright, 1987)

$$
\tau_{z y}=\tau_{0}+\eta_{z y}\left(\varepsilon_{y}\right)^{n}
$$

where $\tau_{0}$ is the stress required to initiate flow (and $n=1$ for a Bingham substance (Cas and Wright, 1987). Viscosity at depth $z$ and cross-flow distance $y\left(\eta_{z y}\right)$ is calculated from (Cigolini et al., 1984)

$$
\eta_{z y}=\left[\rho g \sin (\alpha)\left(d-h_{\mathrm{p}}\right)^{2}\right] /\left[\beta v_{x y}\right],
$$

where $\beta$ has a value of 3 for broad flows (Cas and Wright, 1987; Chester et al., 1985).

\section{ACKNOWLEDGMENTS}

Field work was funded by a National Science Foundation grant and subsequent work was sup- 
ported by National Aeronautics and Space Administration Landsat 7 grant NAG5-3951. The final form of this manuscript benefited from reviews by Mike Ramsey, Barry Cameron and Eugene Smith.

\section{REFERENCES CITED}

Anderson, S.W., Fink, J.H., and Rose, W.I., 1995, Mount St. Helens and Santiaguito lava domes: The effect of short-term eruption rate on surface texture and degassing processes: Journal of Volcanology and Geothermal Research, v. 69 , p. $105-116$.

Archambault, C., and Tanguy, J.C., 1976, Comparative temperature measurements on Mount Etna lavas, problems and techniques: Journal of Volcanology and Geothermal Research, v. 1, p. 113-125.

Bacon, C.R., 1977, High temperature heat content and heat capacity of silicate glasses: Experimental determination and a model for calculation: American Journal of Science, v. 277, p. 109-135.

Blake, S., 2000, Comment on Cooling and Crystallization of lava in open channels, and the transition from pāhoehoe to 'a'ā: Bulletin of Volcanology, v. 62 (4-5), p. 362-364.

Blong, R.J., 1984, Volcanic hazards: Sydney, Australia, Academic Press, 424 p.

Booth, B., and Self, S., 1973, Rheological features of the 1971 Mount Etna lava: Philosophical Transactions of the Royal Society of London, v. 274, p. 99-106.

Borgia, A., and Linneman, S.R., 1990, On the mechanisms of lava flow emplacement and volcano growth: Arenal, Costa Rica, in Fink, J.H., ed., Lava flows and domes: Berlin, Germany, Springer-Verlag, p. 208-243.

Borgia, A., Linneman, S., Spencer, D., Diego Morales, L., and Brenes Andre, J., 1983, Dynamics of lava flow fronts, Arenal volcano, Costa Rica: Journal of Volcanology and Geothermal Research, v. 19, p. 303-329.

Cas, R.A.F., and Wright, J.V., 1987, Volcanic successions: London, Chapman and Hall, 528 p.

Cashman, K.V., Thornber, C., and Kauahikaua, J.P., 1999, Cooling and crystallization of lava in open channels, and the transition of pahoehoe lava to 'a'a: Bulletin of Volcanology, v. 61, p. 306-323.

Chester, D.K., Duncan, A.M., Guest, J.E., and Kilburn, C.R.J., 1985, Mount Etna: The anatomy of a volcano: London, Chapman and Hall, 404 p.

Cigolini, C., Borgia, A., and Castertano, L., 1984, Intracrater activity, aa-block lava, viscosity and flow dynamics: Arenal volcano, Costa Rica: Journal of Volcanology and Geothermal Research, v. 20, 155-176.

Dragoni, M., 1993, Modelling the rheology and cooling of lava flows, in Kilburn, C.R.J., and Luongo, G., eds., Active lavas: London, UCL Press, p. 235-261.

Fink, J.H., 1993, The emplacement of silicic lava flows and associated hazards, in Kilburn, C.R.J., and Luongo, G., eds., Active lavas: London, UCL Press, p. 5-24.

Fink, J.H., and Kieffer, S.W., 1993, Estimate of pyroclastic flow velocities resulting from explosive decompression of lava domes: Nature, v. 363, p. 612-615.

Fink, J.H., and Manley, C.R., 1989, Explosive volcanic activity generated from within advancing silicic lava flows, in Latter, J.H., ed., IAVCEI proceedings in volcanology I: Volcanic hazards: Berlin, Springer-Verlag, p. $169-179$.

Flynn, L.P., and Mouginis-Mark, P.J., 1994, Temperature of an active lava channel from spectral measurements, Kilauea volcano, Hawaii: Bulletin of Volcanology, v. 56 , p. $297-301$.

Flynn, L.P., Harris, A.J.L., Rothery, D.A., and Oppenheimer, C., 2000, Landsat and hyperspectral analyses of active lava flows, in Mouginis-Mark, P., Fink, J., and Crisp, J., eds., Remote sensing of active volcanism: American Geophysical Union Geophysical Monograph Series, v. 116, p. 161-177.

Flynn, L.P., Harris, A.J.L., and Wright, R., 2001, Improved identification of volcanic features using Landsat 7 ETM+: Remote Sensing of Environment, v. 73, p. 180-193.
Francis, P., 1993, Volcanoes: Oxford, UK, Clarendon Press, $443 \mathrm{p}$.

Friedman, J.D., Frank, D., Kieffer, H.H., and Sawatzky, D.L., 1981, Thermal infrared surveys of the May 19 crater, subsequent lava domes, and associated volcanic deposits: U.S. Geological Survey Professional Paper 1250, p. 257-278.

Fujii, T., and Nakada, S., 1999, The 15 September 1991 pyroclastic flows at Unzen volcano (Japan): A flow model for associated ash-cloud surges: Journal of Volcanology and Geothermal Research, v. 89, p. $159-172$.

Gauthier, F., 1973, Field and laboratory studies of the rheology of Mount Etna lava: Philosophical Transactions of the Royal Society of London, v. 274, p. 83-98.

Giberti, G., Jaupart, C., and Sartoris, G., 1992, Steady-state operation of Stromboli volcano, Italy: Constraints on the feeding system: Bulletin of Volcanology, v. 54, p. 535-541.

Harris, A.J.L., and Rowland, S.K., 2001, FLOWGO: A kinematic thermo-rheological model for lava flowing in a channel: Bulletin of Volcanology, v. 63, p. 20-24.

Harris, A.J.L., and Thornber, C.R., 1999, Complex effusion rates at Kilauea as documented by the GOES satellite and remote video cameras: Bulletin of Volcanology, v. 61 , p. 382-395.

Harris, A.J.L., Flynn, L.P., Keszthelyi, L., Mouginis-Mark, P.J., Rowland, S.K., and Resing, J.A., 1998, Calculation of lava effusion rates from Landsat TM data: Bulletin of Volcanology, v. 60, p. 52-71.

Harris, A.J.L., Murray, J.B., Aries, S.E., Daview, M.A. Flynn, L.P., Wooster, M.J., Wright, R., and Rothery, D.A., 2000, Effusion rate trends at Etna and Drafla and their implications for eruptive mechanisms: Journal of Volcanology and Geothermal Research, v. 102 (3-4), p. 237-369.

Heslop, S.E., Wilson, L., Pinkerton, H., and Head, J.W., III, 1989, Dynamics of a confined lava flow on Kilauea volcano, Hawaii: London, Bulletin of Volcanology, v. 51, p. $415-432$.

Holman, J.P., 1992, Heat transfer: McGraw Hill, 713 p.

Hon, K., Kauahikaua, J., Denlinger, R., and Mackay, K., 1994, Emplacement and inflation of pahoehoe sheet flows: Observations and measurements of active lava flows on Kilauea volcano, Hawaii: Geological Society of America Bulletin, v. 106, p. 351-370.

Johnson, T.V., Matson, D.L., Blaney, D.L., Veeder, G.J., and Davies, A., 1995, Stealth plumes on Io: Geophysical Research Letters, v. 22, p. 3293-3296.

Kauahikaua, J., Cashman, K.V., Mattox, T.N., Heliker, C.C., Hon, K.A., Mangan, M.T., and Thornber, C.R., 1998 , Observations on basaltic lava streams in tubes from Kilauea volcano, island of Hawai'i: Journal of Geophysical Research, v. 103, p. 27303-27323.

Keszthelyi, L., 1995, A preliminary thermal budget for lava tubes on the Earth and planets: Journal of Geophysical Research, v. 100, p. 20411-20420.

Keszthelyi, L., and Self, S., 1998, Some physical requirements for the emplacement of long basaltic lava flows: Journal of Geophysical Research, v. 103 , p. 27447-27464.

Kilburn, C.R.J., 1993, Lava crusts, aa flow lengthening and the pahoehoe-aa transition, in Kilburn, C.R.J., and Luongo, G., eds., Active lavas: London, UCL Press, p. 263-280.

Kilburn, C.R.J., and Guest, J.E., 1993, Aa lavas of Mount Etna, Sicily, in Kilburn, C.R.J., and Luongo, G., eds., Active lavas: London, UCL Press, p. 73-106.

Kimberly, P., 1995, Changing volcaniclastic sedimentary patterns at Santa Maria volcano, Guatemala, detected with sequential Thematic Mapper data, 1987-95 [M.Sc. thesis]: Houghton, Michigan Technologica University, $59 \mathrm{p}$

Linneman, S.R., and Borgia, A., 1993, The blocky andesitic lava flows of Arenal volcano, Costa Rica, in Kilburn, C.R.J., and Luongo, G., eds., Active lavas: London, UCL Press, p. 25-72.

Lipman, P.W., and Banks, N.G., 1987, Aa flow dynamics, Mauna Loa 1984: U.S. Geological Survey Professional Paper 1350, p. 1529-1567

Macdonald, G.A., 1953, Pahoehoe, aa, and block lava: American Journal of Science, v. 251, p. 169-191.
Macdonald, G.A., 1972, Volcanoes: Englewood Cliffs, New Jersey, Prentice-Hall, 510 p.

Manley, C.R., 1992, Extended cooling and viscous flow of large, hot rhyolite lavas: Implications of numerical modeling results: Journal of Geophysical Research, v. 53 , p. $27-46$

Mellors, R.A., Waitt, R.B., and Swanson, D.A., 1988, Generation of pyroclastic flows and surges by hot-rock avalanches from the dome of Mount St. Helens volcano, USA: Bulletin of Volcanology, v. 50, p. 14-25.

Moore, H.J., 1987, Preliminary estimates of the rheological properties of 1984 Mauna Loa lava: U.S. Geological Survey Professional Paper 1350, p. 1569-1588.

Murase, T., and McBirney, A., 1973, Properties of some common igneous rocks and their melts at high temperatures: Geological Society of America Bulletin, v. 84 , p. $3563-3592$.

Oppenheimer, C., 1991, Lava flow cooling estimated from Landsat Thematic Mapper infrared data: The Lonquimay eruption (Chile, 1989): Journal of Geophysical Research, v. 96, p. 21865-21878.

Oppenheimer, C., Francis, P.W., Rothery, D.A., Carlton, R.W.T., and Glaze, L.S., 1993, Infrared image analysis of volcanic thermal features: Lascar volcano, Chile, 1984-1992: Journal of Geophysical Research, v. 98, p. 4269-4286.

Peterson, D.W., and Tilling, R.I., 1980, Transition of basaltic lava from pahoehoe to aa, Kilauea volcano, Hawaii: Field observations and key factors: Journal of Volcanological and Geothermal Research, v. 7, p. 271-293.

Pieri, D.C., and Baloga, S., 1986, Eruption rate, area, and length relationships for some Hawaiian lava flows: Journal of Volcanological and Geothermal Research, v. 30 , p. $29-45$.

Pieri, D.C., Glaze, L.S., and Abrams, M.J., 1990, Thermal radiance observations of an active lava flow during the June 1984 eruption of Mount Etna: Geology, v. 18 , p. $1018-1022$.

Pinkerton, H., and Sparks, R.S.J., 1976, The 1975 subterminal lavas, Mount Etna: A case history of the formation of a compound lava field: Journal of Volcanological and Geothermal Research, v. 1, p. 167-182.

Pinkerton, H., and Sparks, R.S.J., 1978, Field measurements of the rheology of lava: Nature, v. 276, p. 383-385.

Pitts, D.R., and Sissom, L.E., 1997, Heat transfer: New York, McGraw Hill, 365 p.

Ramsey, M.S., Harris, A.J.L., Dehn, J., and Pirie, D., 2001 , Thermal anomaly monitoring of the ongoing eruptions at Soufriere Hills volcano, Montserrat and Bezymianny volcano, Kamchatka: First results from the new ASTER instrument [abs. U31A-08]: Eos (Transactions, American Geophysical Union), v. 81, no. 19 p. 20.

Robertson, E.C., and Peck, D.L., 1974, Thermal conductivity of vesicular basalt from Hawaii: Journal of Geophysical Research, v. 79, p. 4875-4888.

Rose, W.I., 1972, Pattern and mechanism of volcanic activity at the Santiaguito volcanic dome, Guatemala: Bulletin of Volcanology, v. 36, p. 73-94.

Rose, W.I., 1987a, Volcanic activity at Santiaguito volcano, 1976-1984, in Fink, J.H., ed., The emplacement of silicic domes and lava flows: Geological Society of America Special Paper 212, p. 17-28.

Rose, W.I., 1987b, Santa Maria, Guatemala: Bimodal sodarich calc-alkalic stratovolcano: Journal of Volcanological and Geothermal Research, v. 33, p. 109-129.

Rose, W.I., Pearson, T., and Bonis, S., 1976, Nuée ardente eruption from the foot of a dacite lava flow, Santiaguito volcano, Guatemala: Bulletin of Volcanology, v. 40 , p. $23-38$.

Rothery, D.A., Francis, P.W., and Wood, C.A., 1988, Volcano monitoring using short wavelength infrared data from satellites: Journal of Geophysical Research, v. 93, p. 7993-8008.

Rowland, S.K., and Walker, G.P.L., 1987, Toothpaste lava: Characteristics and origin of a lava structural type transitional between pahoehoe and aa: Bulletin of Volcanology, v. 49, p. 631-641.

Salisbury, J.W., and D'Aria, D.M., 1992, Emissivity of terrestrial materials in the $8-14 \mu \mathrm{m}$ atmospheric win- 
dow: Remote Sensing of Environment, v. 42, p. $83-106$.

Scaillet, B., Clemente, B., Evans, B.W., and Pichavant, M., 1998, Redox control of sulfur degassing in silicic magmas: Journal of Geophysical Research, v. 103, p. 23937-23949.

SEAN, 1988a, Santa Maria: Washington, D.C., Smithsonian Institution Scientific Event Alert Network, v. 13, no 2 , p. 1-4.

SEAN, 1988b, Santa Maria: Washington, D.C., Smithsonian Institution Scientific Event Alert Network, v. 13, no. 11 , p. $1-4$

Shaw, H.R., 1969, Rheology of basalt in the melting range: Journal of Petrology, v. 10, p. 510-535.

Simkin, T., and Siebert, L., 1994, Volcanoes of the world: Tucson, Arizona, Geoscience Press, 349 p.

Ui, T., Matsuwo, N., Sumita, M., and Fujinawa, A., 1999 Generation of block and ash flows during the 1990 1995 eruption of Unzen volcano, Japan: Journal of
Volcanological and Geothermal Research, v. 89 p. 123-137.

Voight, B., and Elsworth, D., 2000, Instability and collapse of hazardous gas-pressurized lava domes: Geophysical Research Letters, v. 27, p. 1-4.

Wentworth, C.K., and Macdonald, G.A., 1953, Structures and forms of basaltic rocks in Hawaii. U.S. Geological Survey Bulletin 994, p. 1-98.

Williams, H., and McBirney, A.R., 1979, Volcanology: San Francisco, California, Freeman, Cooper and Company, $397 \mathrm{p}$.

Williams, S.N., and Self, S., 1983, The October 1902 Plinian eruption of Santa Maria volcano, Guatemala: Journal of Volcanological and Geothermal Research, v. 16 , p. $33-56$.

Wooster, M.J., and Rothery, D.A., 1997, Time-series analysis of effusive volcanic activity using the ERS along track scanning radiometer: The 1995 eruption of Fernandina volcano, Galapagos Islands: Remote Sensing of Environment, v. 62, p. 109-117.
Wooster, M.J., Kaneko, T., Nakada, S., and Shimizu, H., 2000 , Discrimination of lava dome activity styles using satellite-derived thermal structures: Journal of Volcanological and Geothermal Research, v. 102, p. $97-118$.

Yamaguchi, Y., Kahle, A.B., Tsu, H., Kawakami, T., and Pniel, M., 1998, Overview of the Advanced Spaceborne Thermal Emission and Reflectance Radiometer (ASTER): IEEE Transactions in Geoscience and Remote Sensing, v. 36, p. 1062-1071.

Yamamoto, T., Takarada, S., and Suto, S., 1993, Pyroclastic flows from the 1991 eruption of Unzen volcano, Japan: Bulletin of Volcanology, v. 55, p. 166-175.

Manuscript Received by the Society December 18, 2000 Revised Manuscript Received November 5, 2001 MANUSCRIPT ACCEPTED DeCEMBer 11, 2001

Printed in the USA 